\title{
Identifying the Effective Factors on Improvement of In-Service Training of Managers of Health Vocational Education and Training Centers; A Qualitative Study
}

\author{
SeyyedAlireza Alavi ${ }^{1}$, Mohammad Hoseeinpour ${ }^{1 *}$, Yadollah Mehralizadeh $^{1}$ \\ 1. Department of Educational Management, Ahvaz Branch, Islamic Azad University, Ahvaz, Iran
}

Received: 19 January 2021

Accepted for publication: 30 January 2021

[EPub a head of print-10 January 2021]

Payesh: 2021; 20 (1):15-29

\begin{abstract}
Objective (s): The present study aimed to identify the effective factors on improvement of in-service training of managers of health vocational education and training centers.

Methods: This qualitative study was performed using semi-structured interviews with 16 faculty members and managers of Academic Center for Education, Culture and Research (ACECR). Thematic analysis method was used for data analysis.

Results: The findings indicated that the improvement of in-service training of managers of vocational health education and training centers are influenced by educational factors, managerial factors and technological factors.

Conclusion: Due to the expansion of ACECR affiliated Health Vocational Education and Training Centers, improvement of In-Service Training of Managers of educational centers needs more attention in this organization. The results of this study can be used as suitable solutions to improve in-service training of manager of vocational health education and training Centers.
\end{abstract}

Key Words: In-Service Training, ACECR, Health Vocational Education and Training, Thematic analysis

\footnotetext{
* Corresponding author: Ahvaz Branch, Islamic Azad University, Ahvaz, Iran

E-mail: hosseinpour6@yahoo.com
} 


\title{
شناسايى عوامل موثر در بهبود آموزشهاى ضمن خدمت مديران مراكز مجرى آموزشهاى مهارتى و حرفاى علوم يزشكى؛ يك مطالعه كيفى
}

\author{
سيدعليرضا علوى'، محمد حسين يور "، يداله مهرعلى زاده'
}

ا. كروه مديريت آموزشى، واحد اهواز، دانشخاه آزاد اسلامى، اهواز، ايران

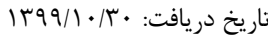

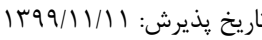

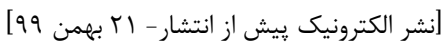

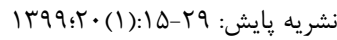

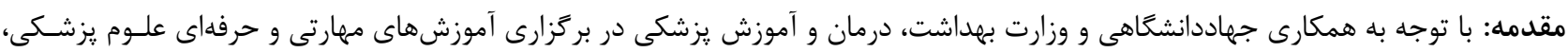

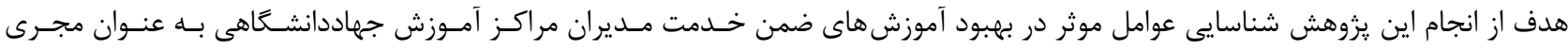

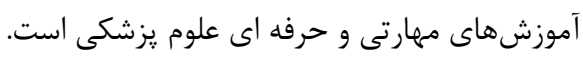

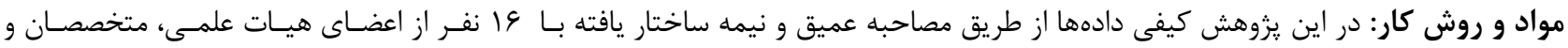

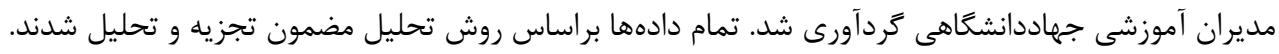

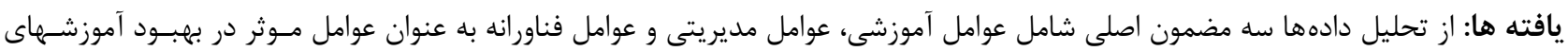
ضمن خدمت مديران مراكز استخراج شد.

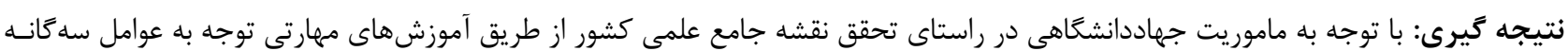

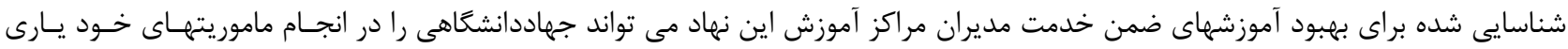


كيفيت آموزشهاى مهارتى و حرفهاى و توسعه آموزشهاى مهارتى و حرفهاى در راستاى نيازهاى جامعه تاسيس كرد. با توجه همزمانى

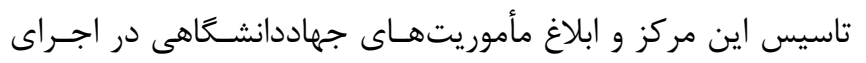

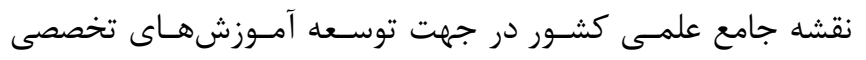

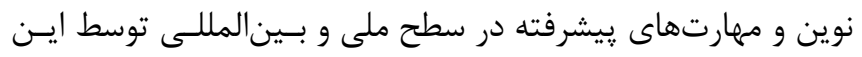

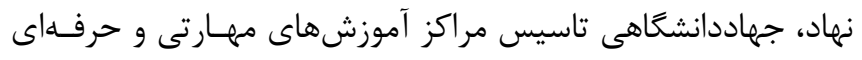

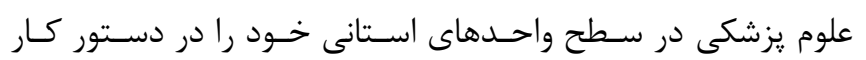

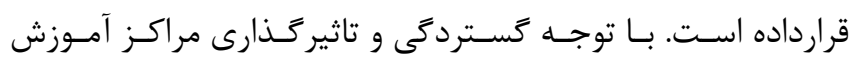

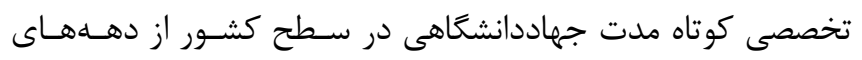

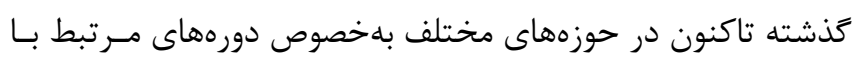

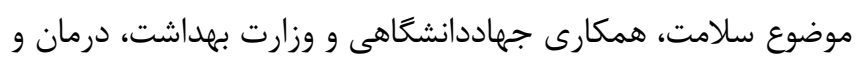

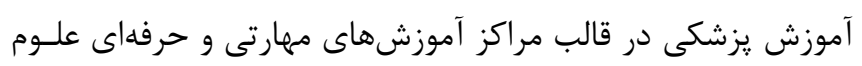

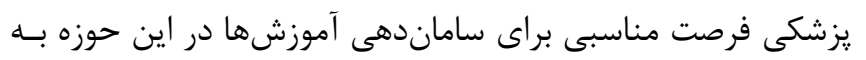

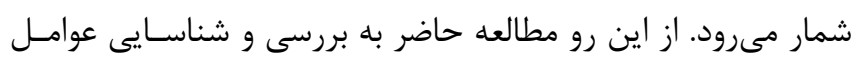

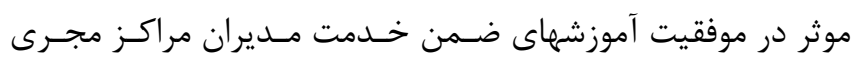

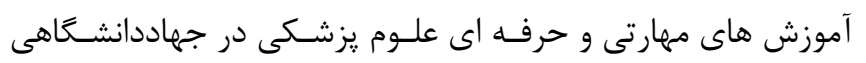

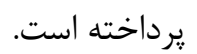

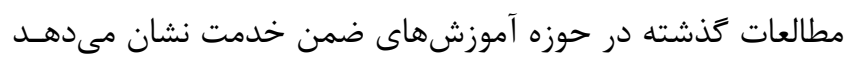

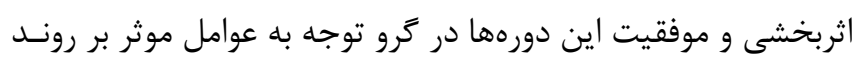

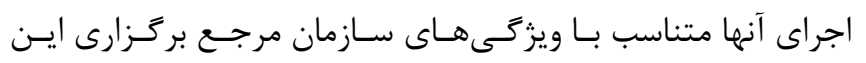

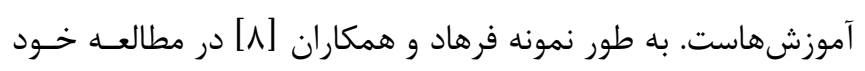

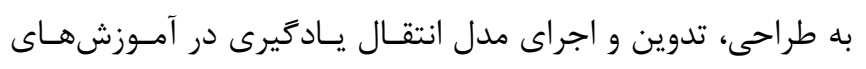

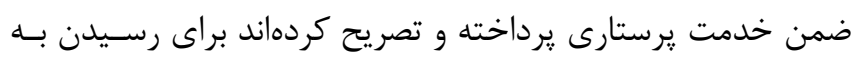

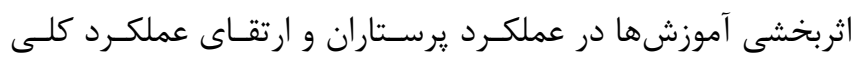

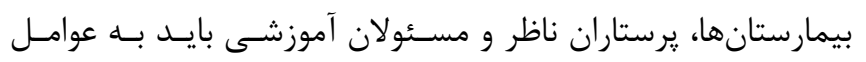

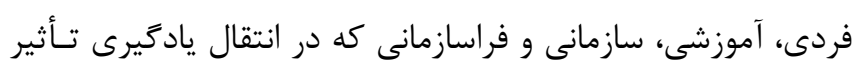

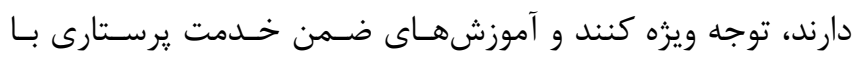

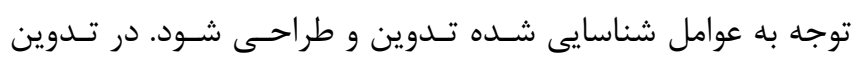

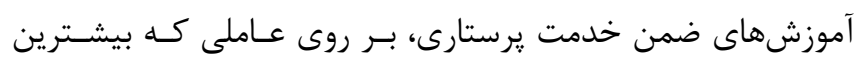

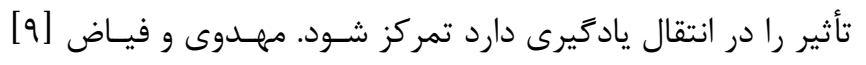

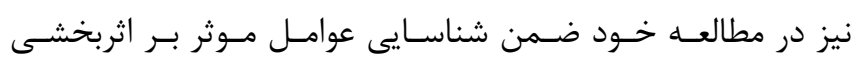

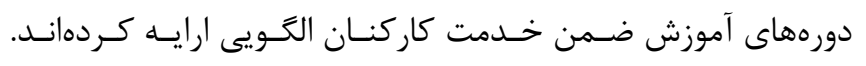

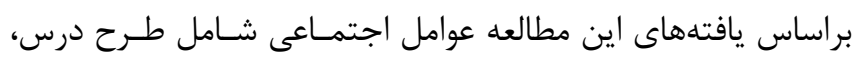

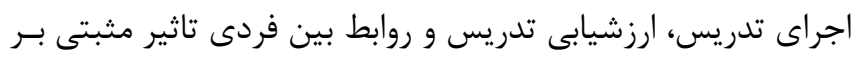

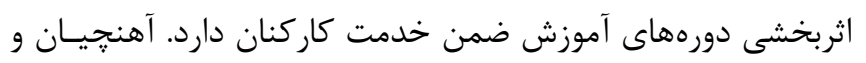

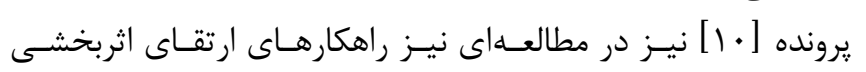

امروزه سازمانها شاهد يك فضاى شغلى به سرعت در حسال تغييـر،

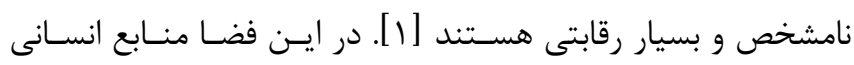

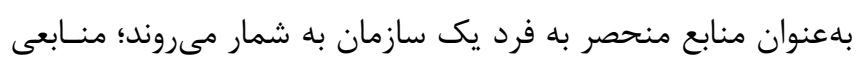

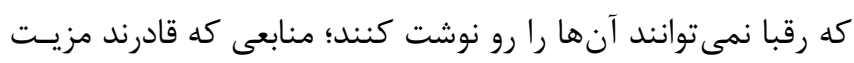

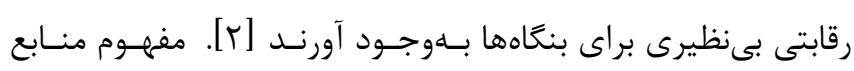

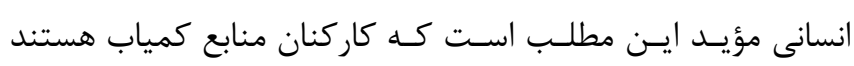

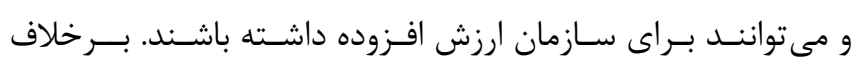

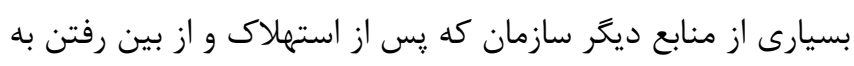

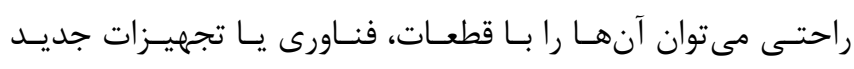

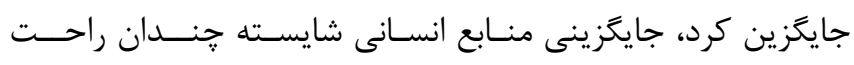

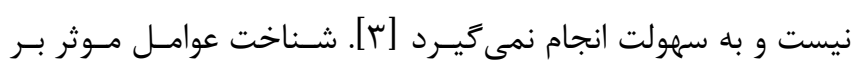

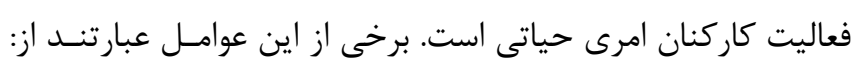

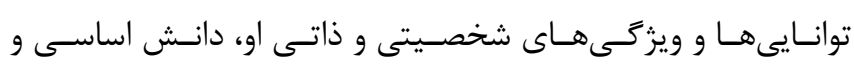

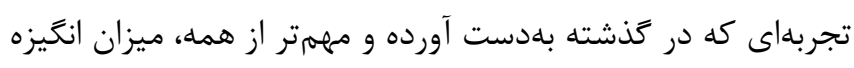

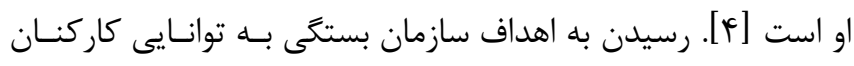

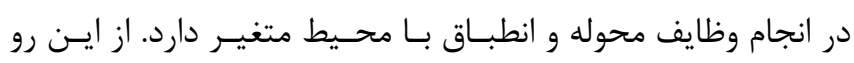

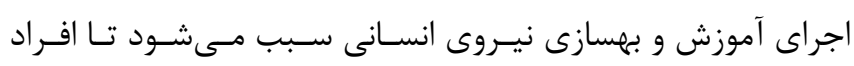

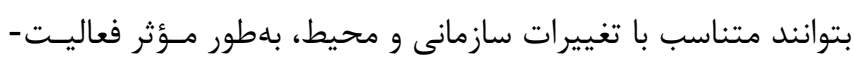

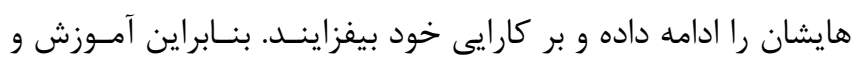

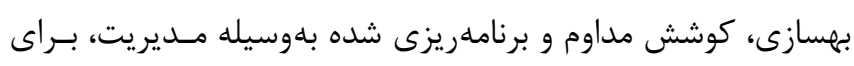

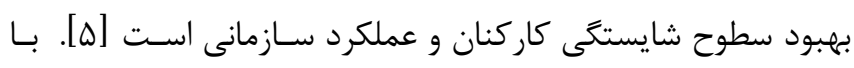

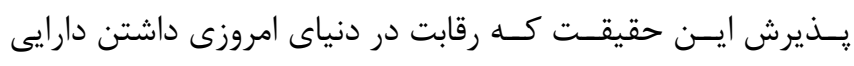

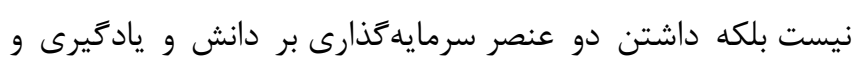

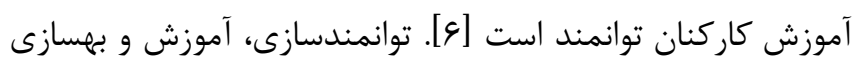

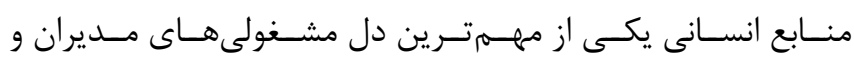

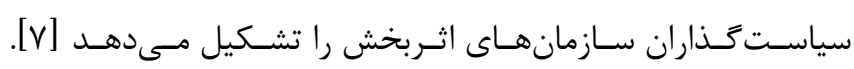

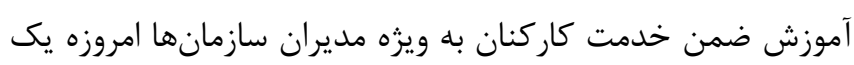

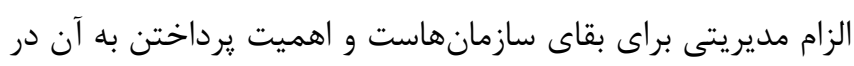

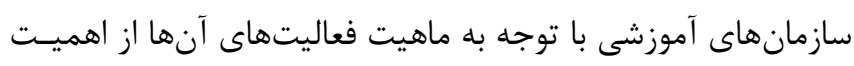

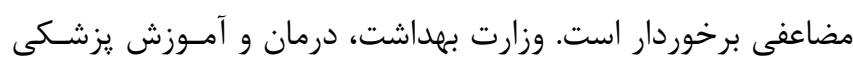

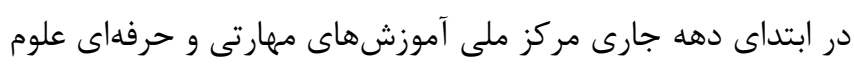

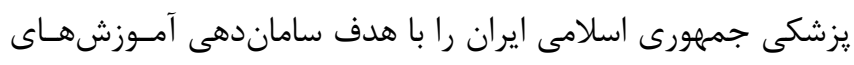

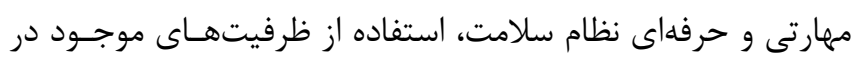

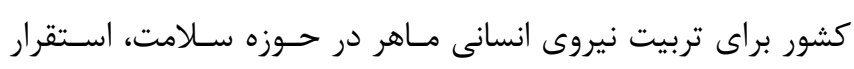

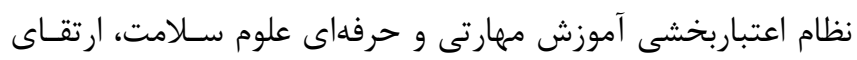


آموزش ضمن خدمت، برنامهريزى منظهم دورهها و استفاده از آموزش

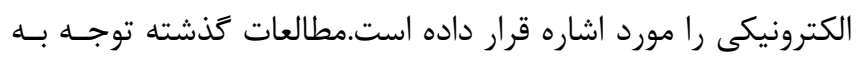

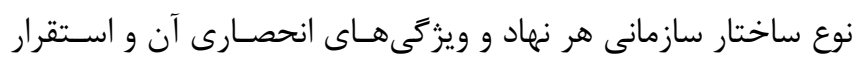

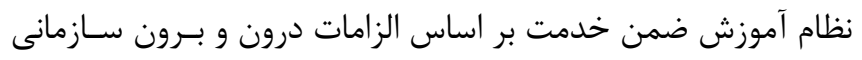

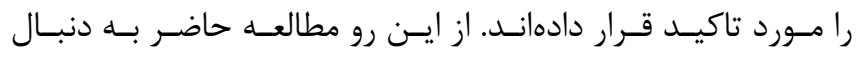

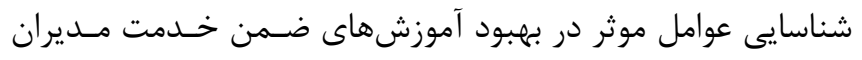

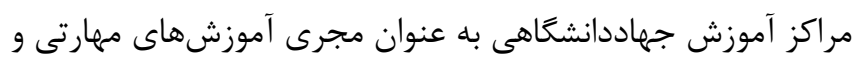
حرفه اي علوم يزشكى بود.

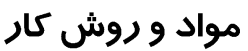

اين مطالعه با رويكردى كيفى اجرا شده اسـت. در ايسن مطالعـه 19

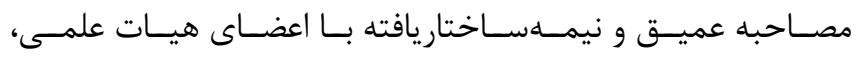
متخصصان و مديران آموزشى جهاددانشكاهى انجام شد. مصاحبههـا

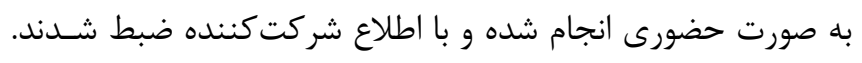

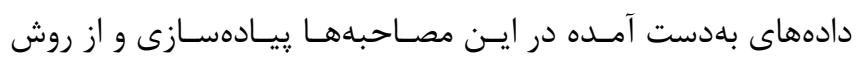

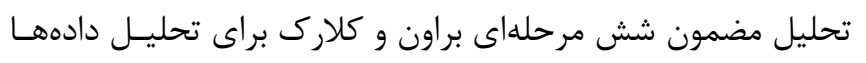

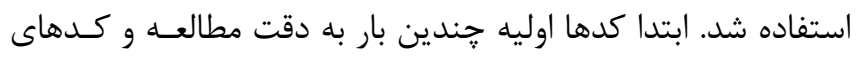

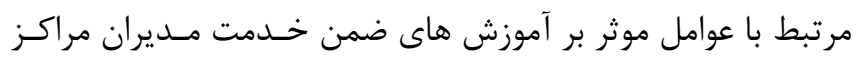

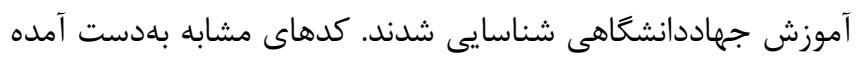

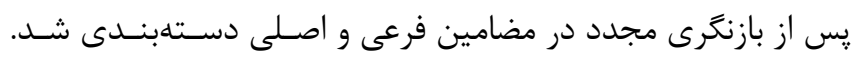

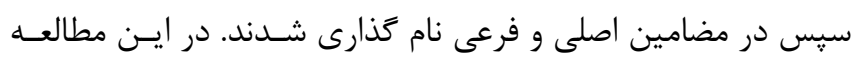

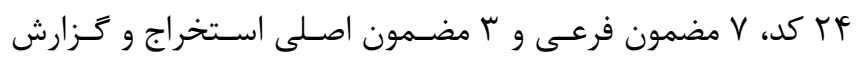

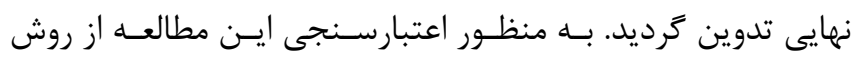

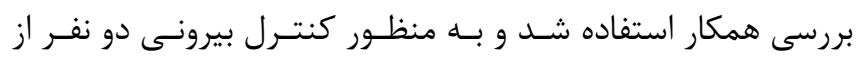

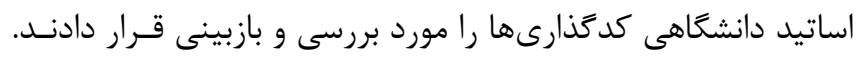

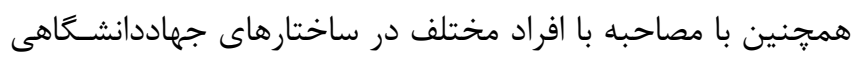

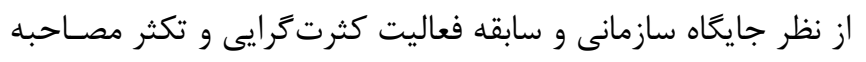

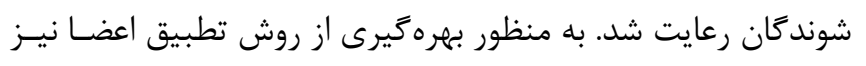

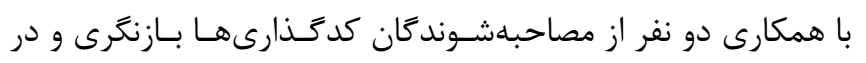
تدوين گزارش نهايى از نظرات آنان استفاده شد.

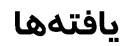

در اين مطالعه كيفى با 19 نفر از اعضاى هيات علمى، متخصصـان و

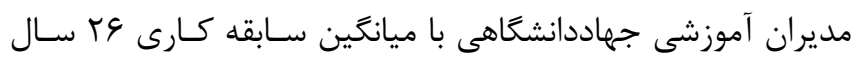

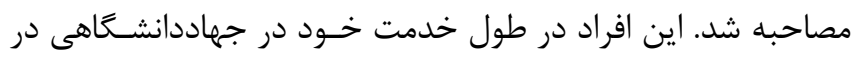

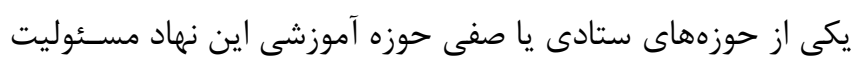

دورههاى آموزشى در سازمانها را بررسى و تصريح كردماند در بـين

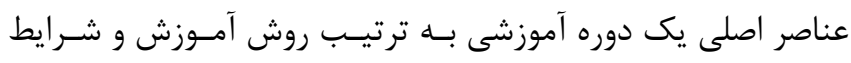

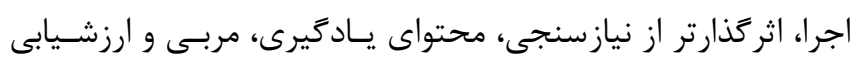

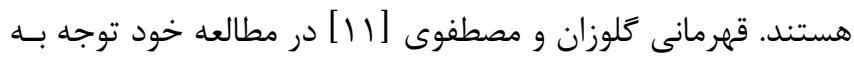

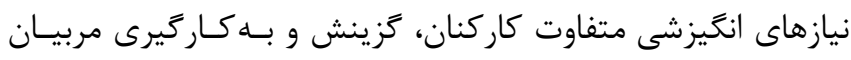

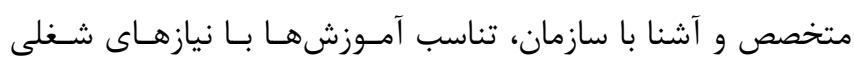

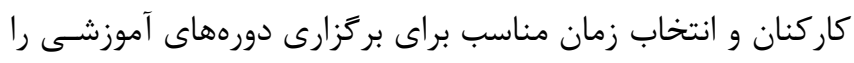

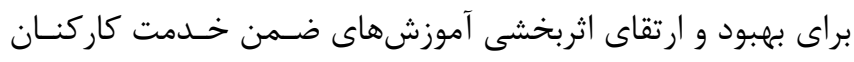

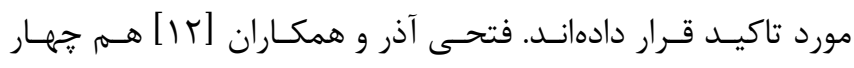

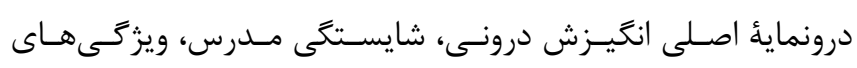

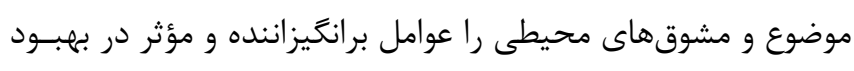

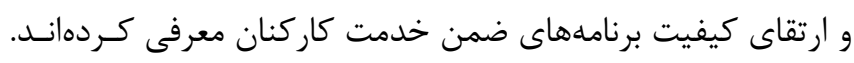

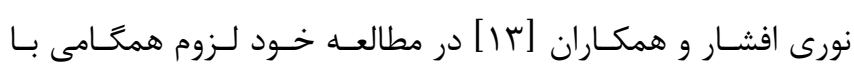

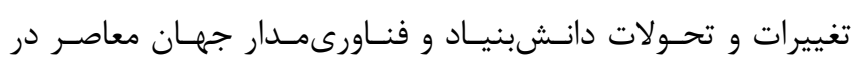

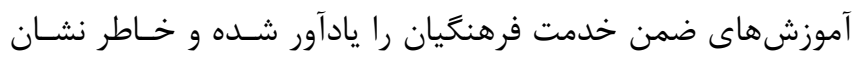

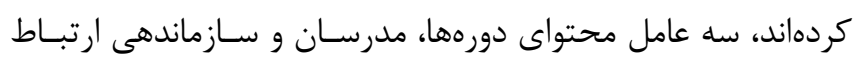

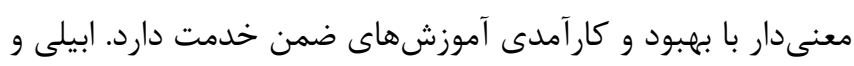

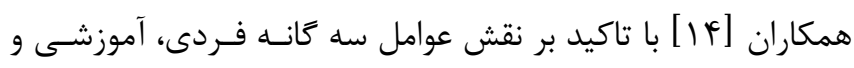

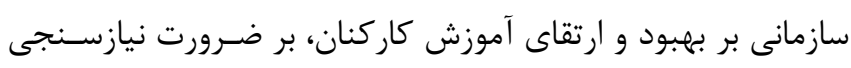

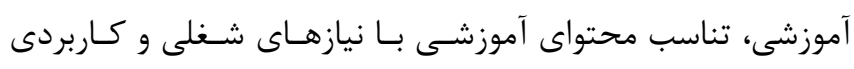

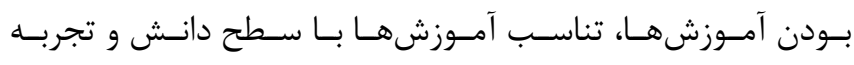

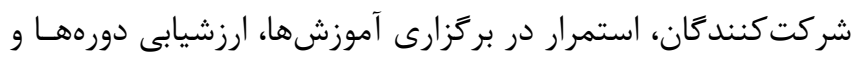

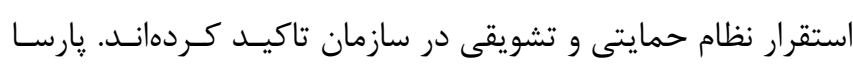

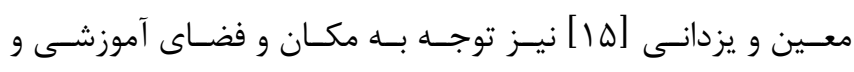

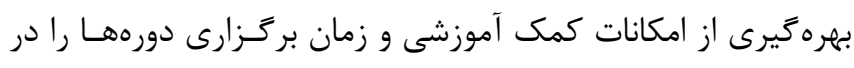

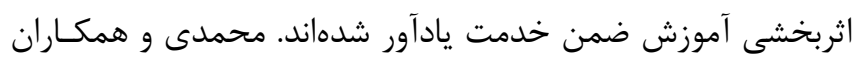

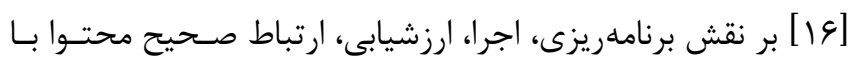

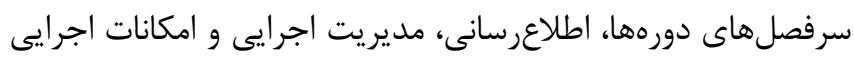

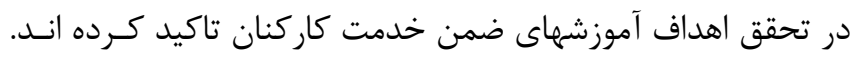

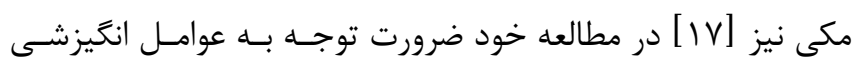

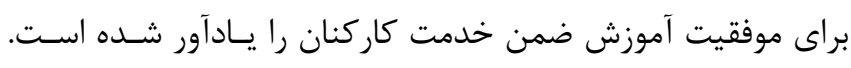

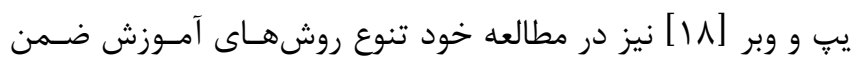

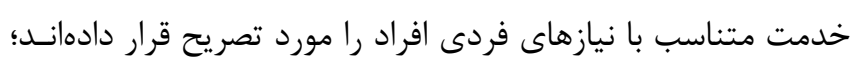

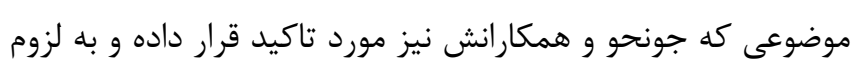

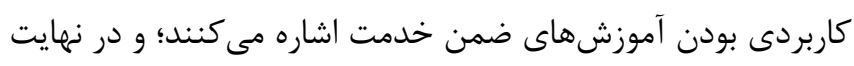

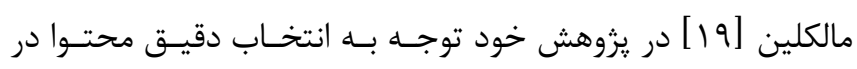


مديران مراكـز مـا هـم كسه معهـولا /ز بـين نيروهـاى نسـبتا جـوان

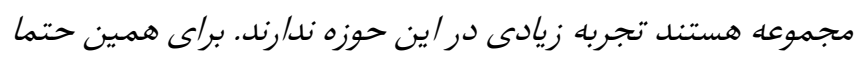

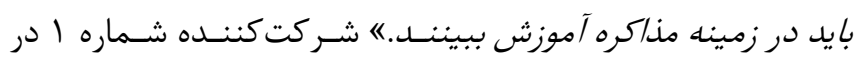

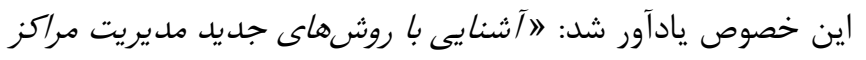

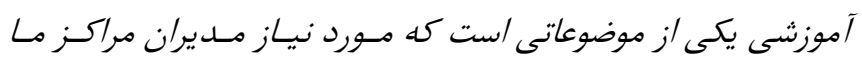

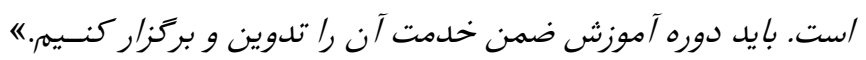

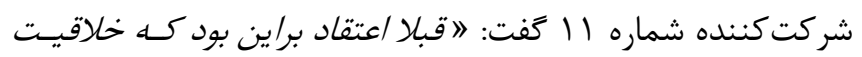

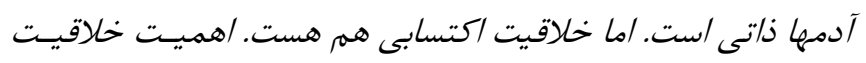

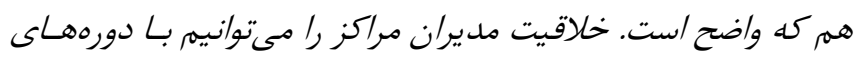

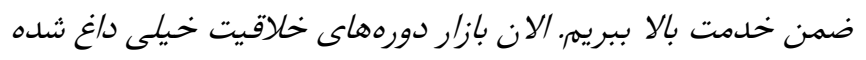

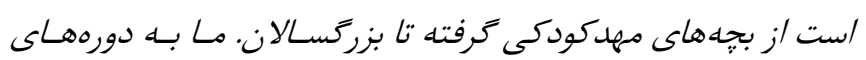

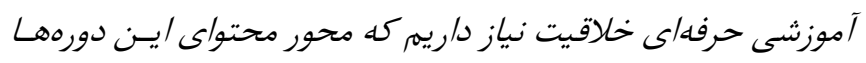

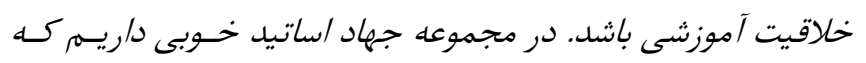

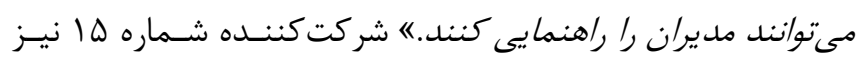

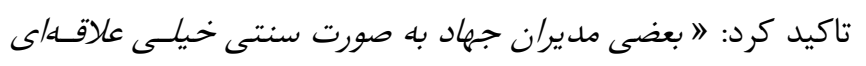

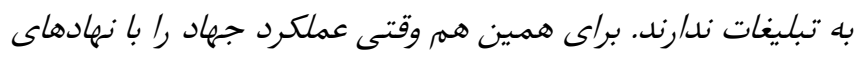

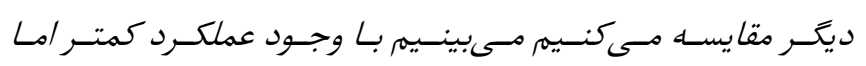

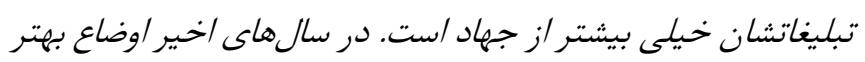

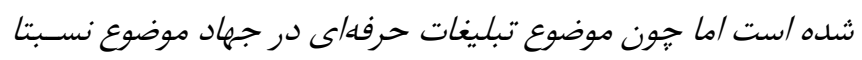

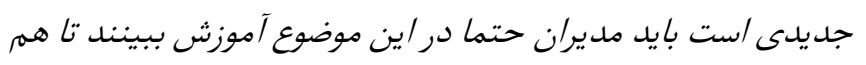

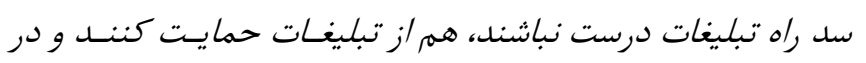

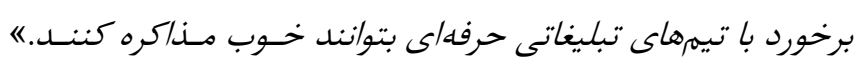

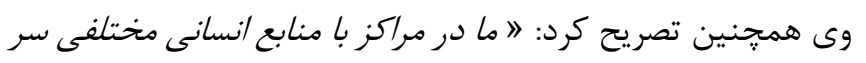

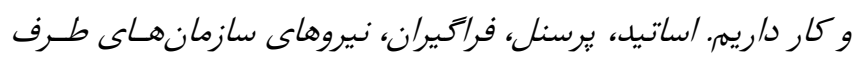

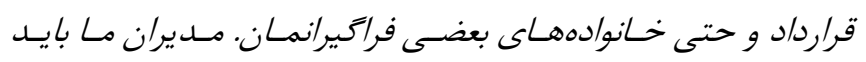

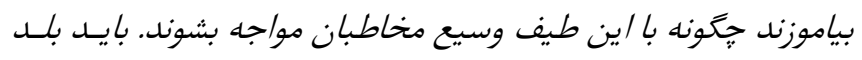

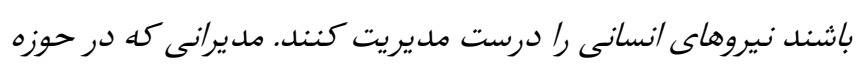

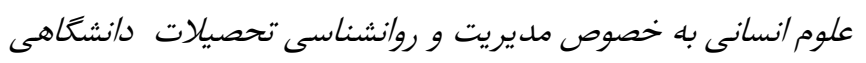

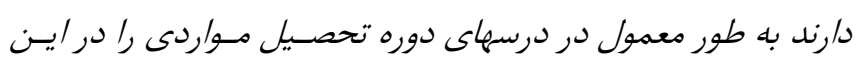

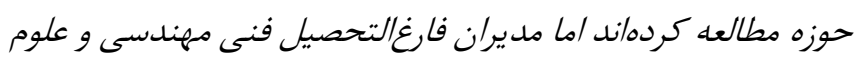

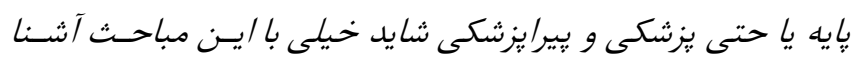

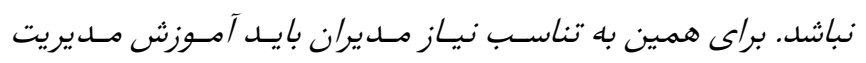

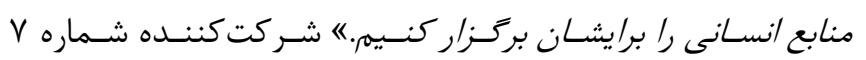

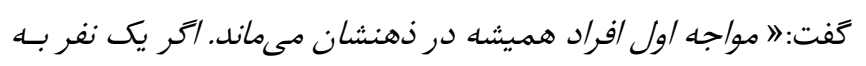

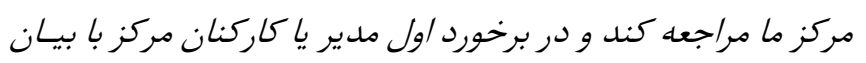

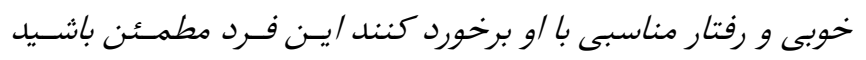

داشتهاند. مشخصات مشاركت كنـــدكان در جـدول شـماره ا آورده

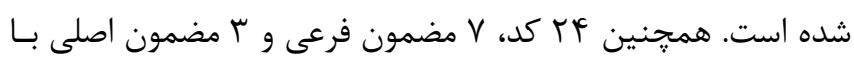

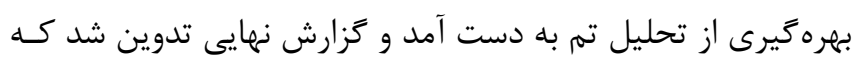

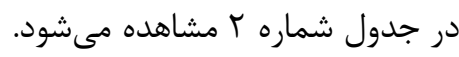

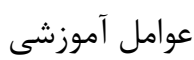

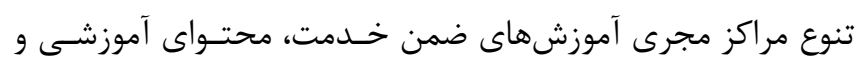

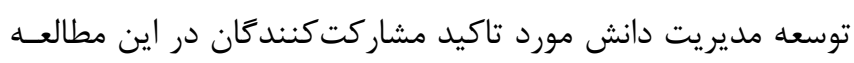

تنوع مراكز مجرى آموزشهاى ضمن خدمت

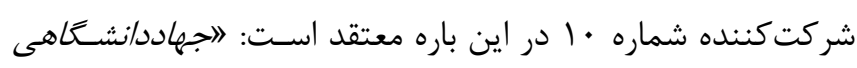

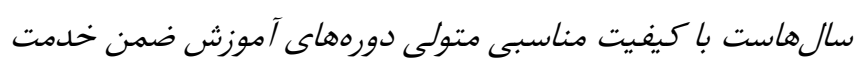

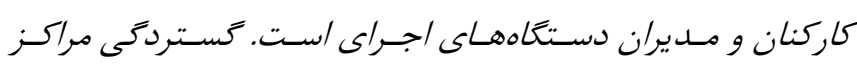

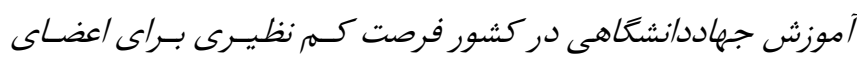

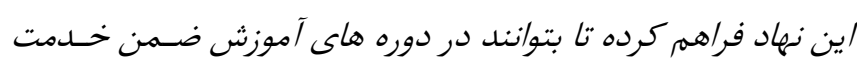

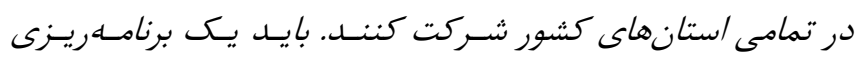

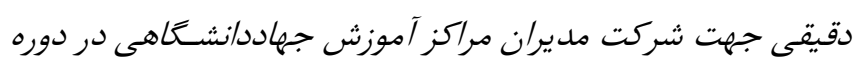

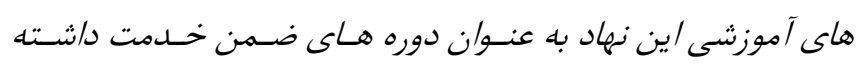

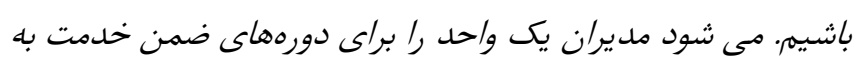

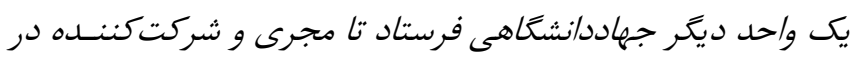

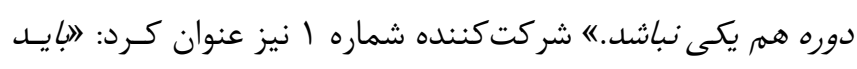

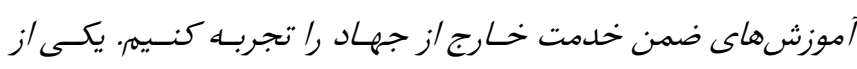

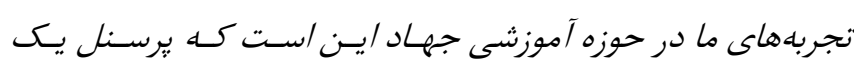

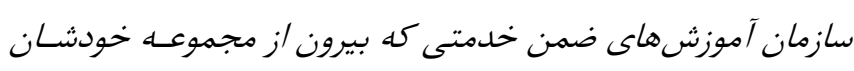

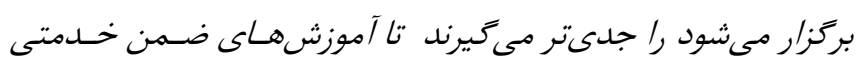

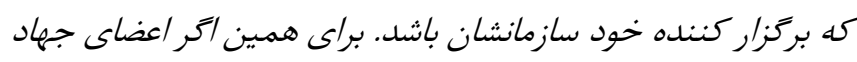

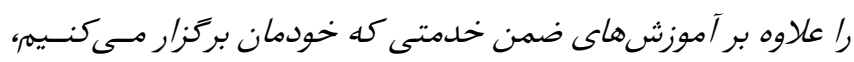

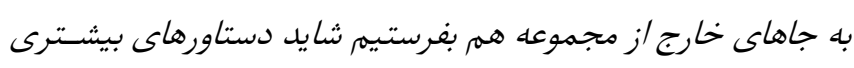

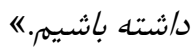

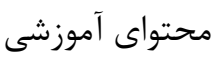

ضروت توجه به محتواى آموزشى يكى ديكر از موارد مـورد اشـاره

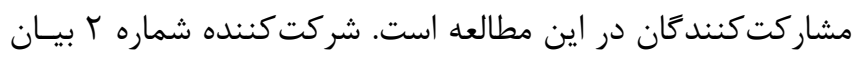

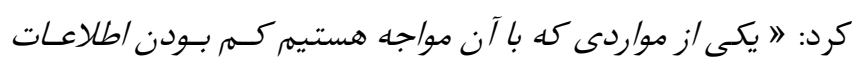

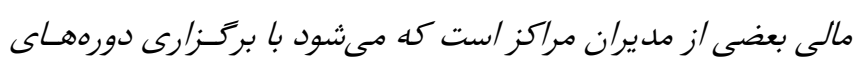

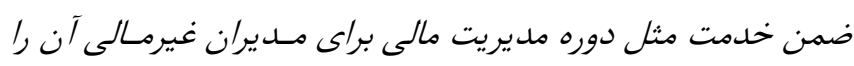

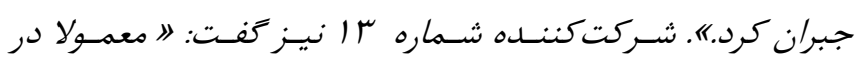

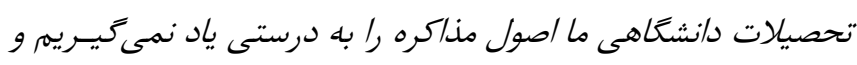


فرصتهاى مطالعاتى داخل كشور

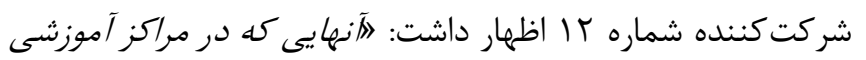

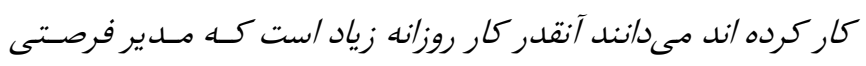

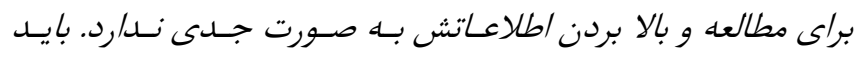

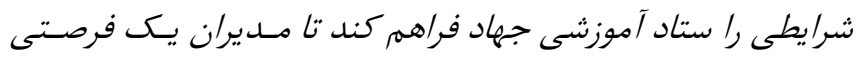

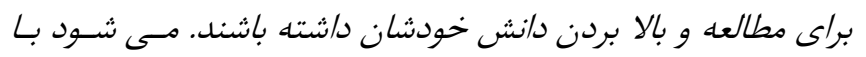

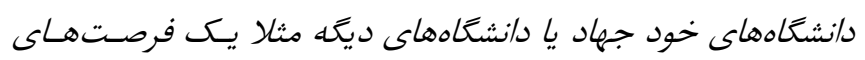

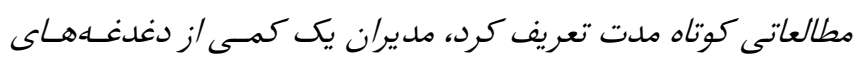

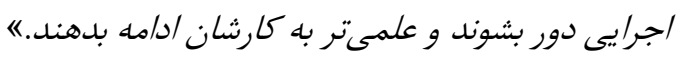
فرصتهاى مطالعاتى خارج كشور

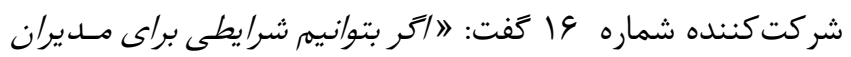

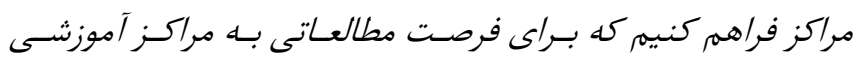

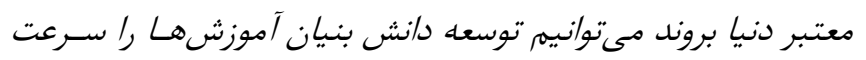

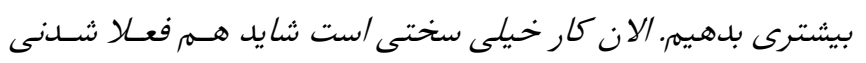

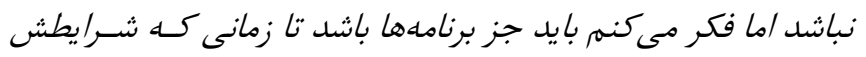

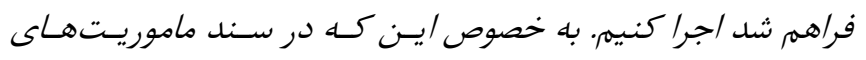

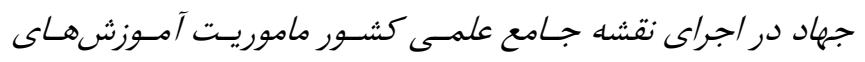

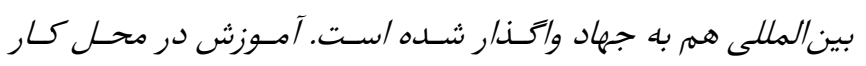

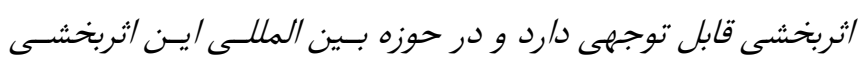
بيشر /ست.

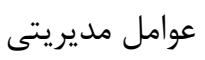
بازنكرى در قوانين و سياسـتهاى آموزشـى دو موضـوع مـورد تاكيـد مشاركت كنند بازنخرى در قوانين

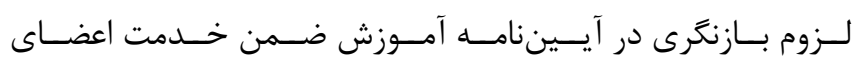

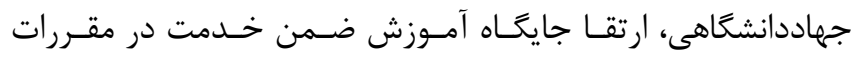

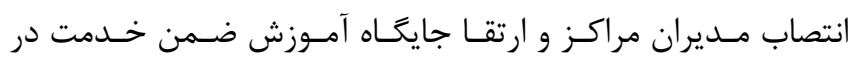

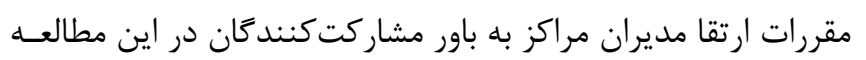
در موفقيت آموزشهاى ضمن خدمت مديران ايفاى نقش مى كند.

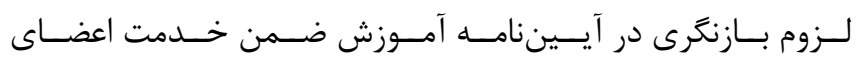
جهاددانشخاهى

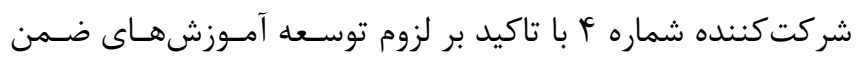

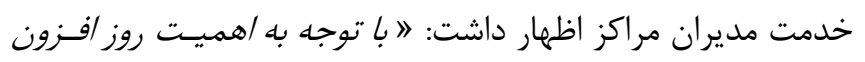

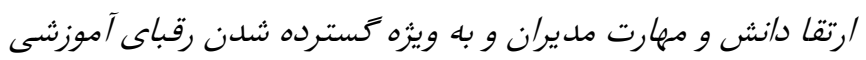

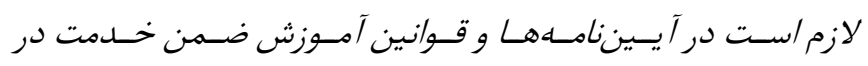

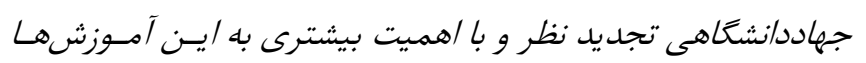

مبلنى براى مركز مىشود. /ز طرف ديكر وقتى مدير ما براى مـذاكره

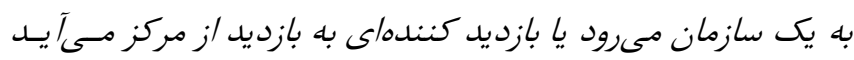

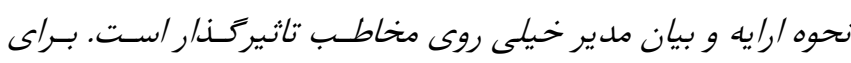

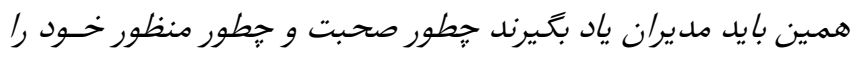

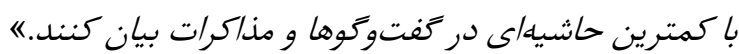
توسعه مديريت دانش حسي

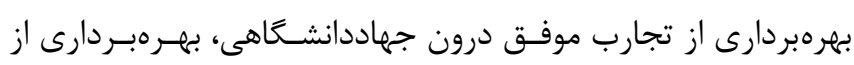

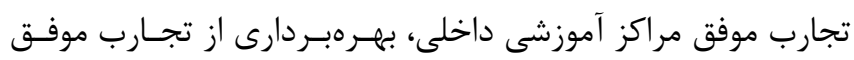

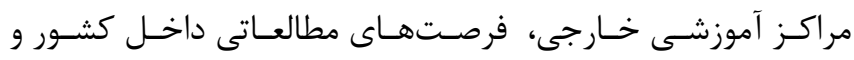

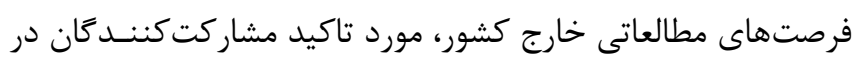

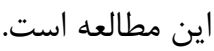

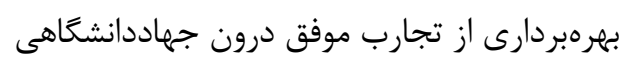

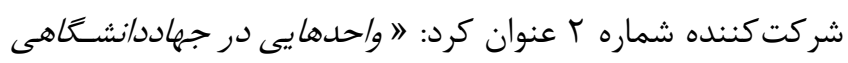

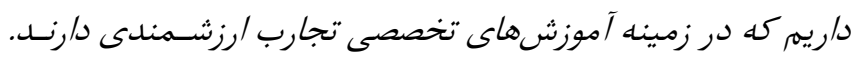

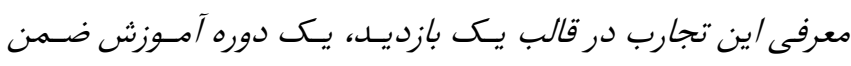

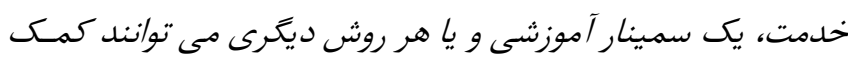

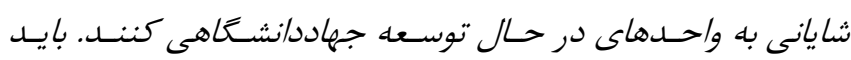

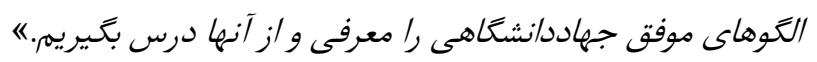

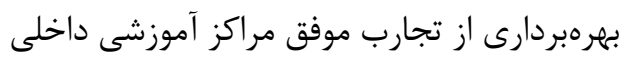

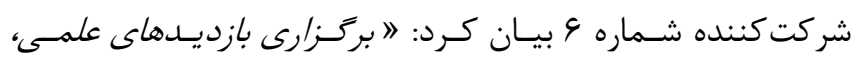

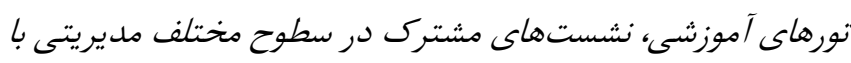

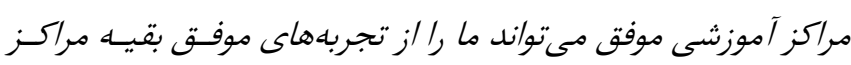

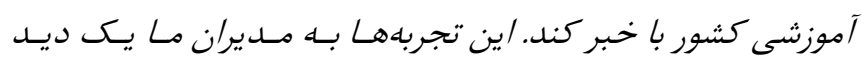
جديلى دركار مسىهند. بهرهبردارى از تجارب موفق مراكز آموزشى خارجى درى

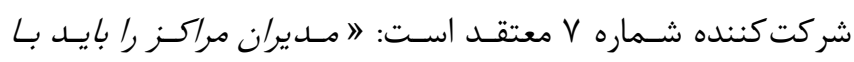
نمونه هاى موفق آموزشسى دنيا آشــا كنــيم. مطالعسه دربـاره مراكـز آموزشى موفق خارج از كشور، /مضا تناهمنامه براى تبادل تجرئ مونيات

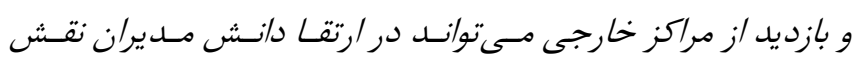
موثرى داشته باشد. تلوين /ين تجارب و مستندسازى آنها يكى بانكى مانى

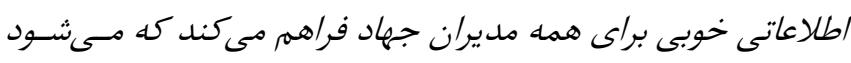

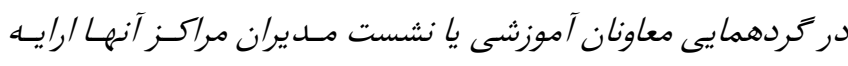

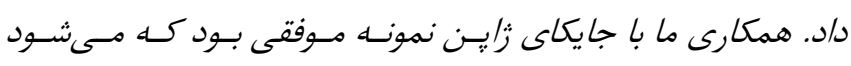

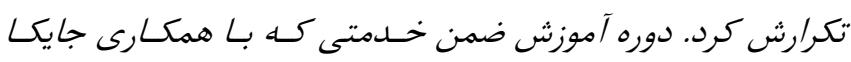

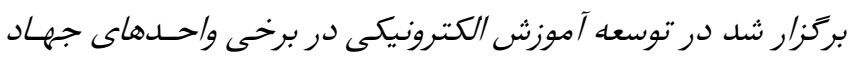

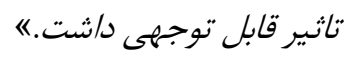


آموزش ضمن خدمت معاونت يشتيبانى جهاد /ست /ما فكر نمىكنم

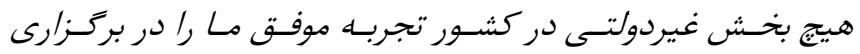

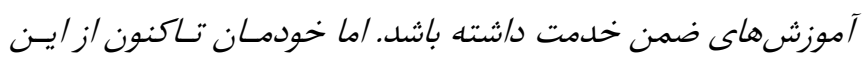

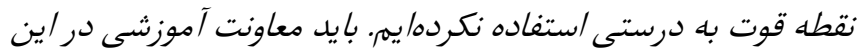
خصوص نقش برزنَترى د/شته باشد."

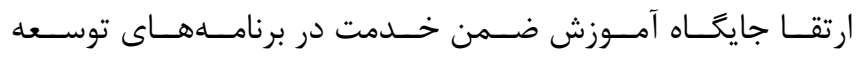

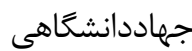
شركت كننده شماره ا كفت: " يكى از كارهايى كه در جهاد به خوبى

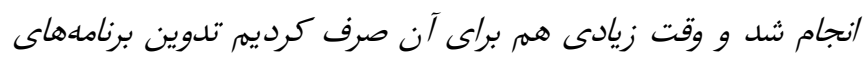

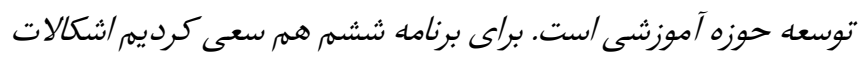

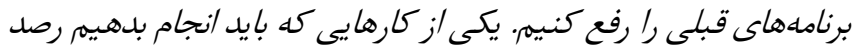

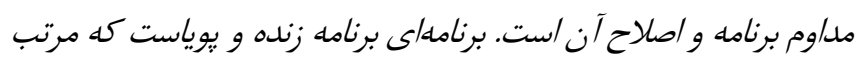

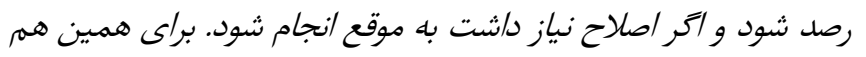

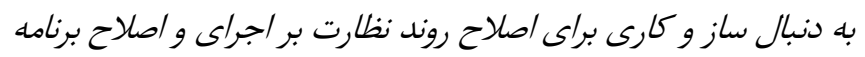

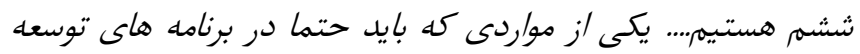

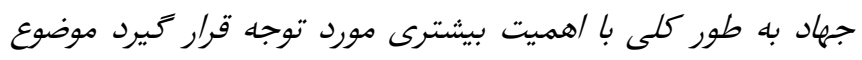

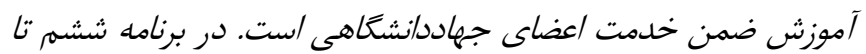
حدودى /ين مساله بهتر ديده شد و بايد در تدوين برنامه هفتم توجه

$$
\begin{aligned}
& \text { بيشترى به آن شود. 《ان مال } \\
& \text { عوامل فناورانه }
\end{aligned}
$$

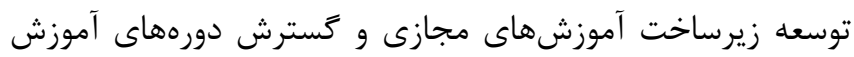

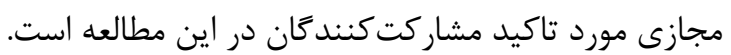

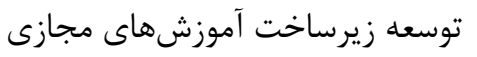
به اعتقاد مشاركت كنندكان در اين مطالعه ارتقان نرمافزاهاى آمـوزش

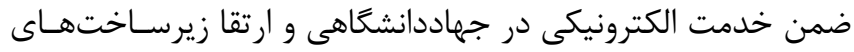

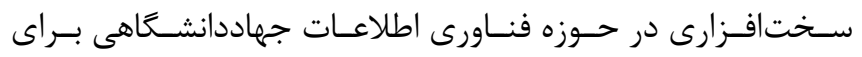
موفقيت آموزش هاى ضمن خدمت مديران ضرورى است.

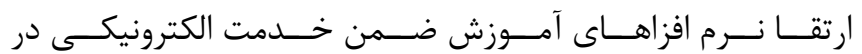
جهاددانشگاهى

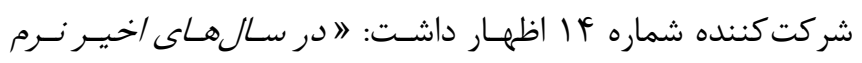
افزارهاى آموزشى خوبى در جهاددانشكاهى مورد /ستفاده قرار كرفته

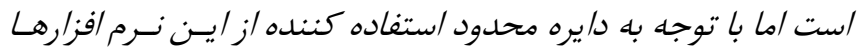

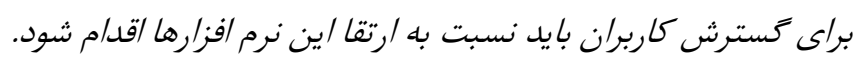

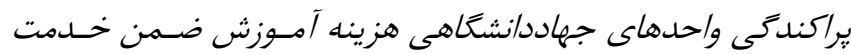
حضورى به صورت متمركز براى مديران مراكز را زياد كرده /سـت و و

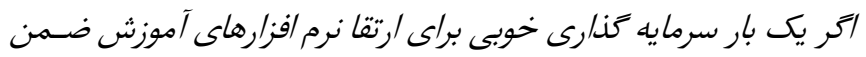

ببرد/زيم. البته اطلاع دارم آييننامه توانمندسـازى و آمـوزش ضـمن خدمت در حال بازنغرى /ست.

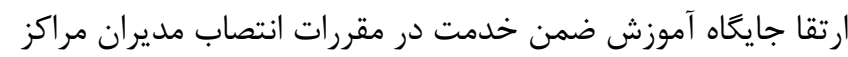

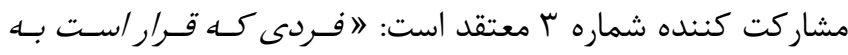

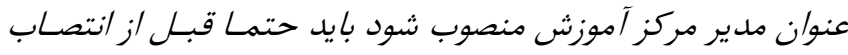

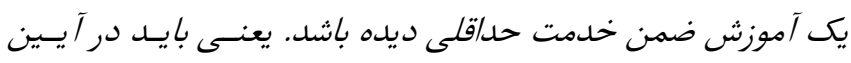

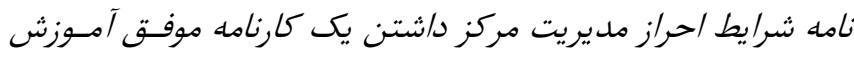

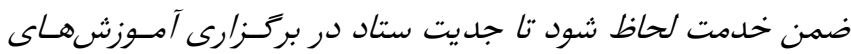

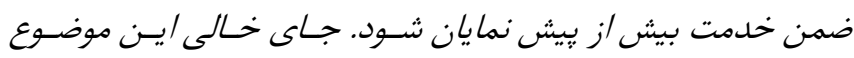
احساس مى شود." إنان

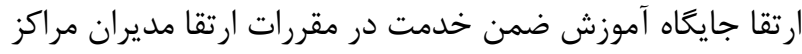

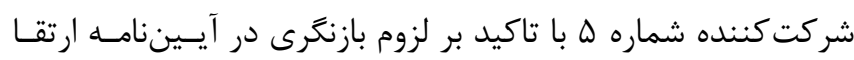

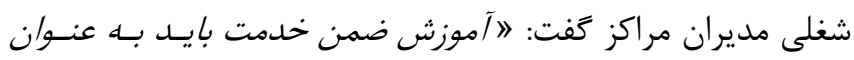
يكى /ز فاكتورهاى /رتقا شغلى مديران مراكز مورد توجه جدى برى باشد.

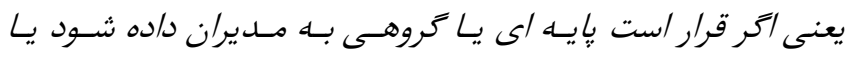

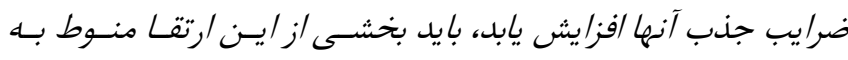

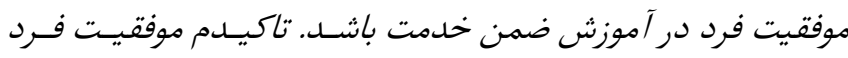

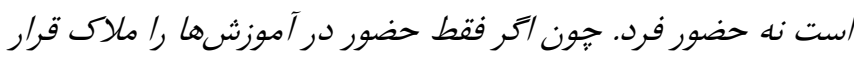

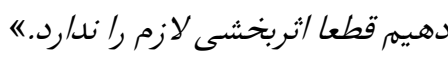

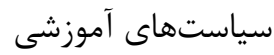

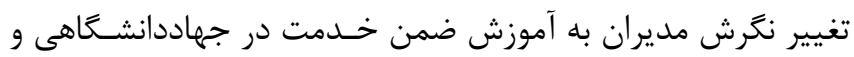

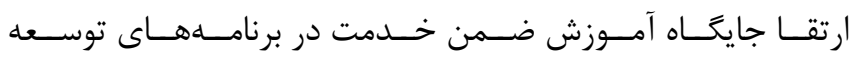

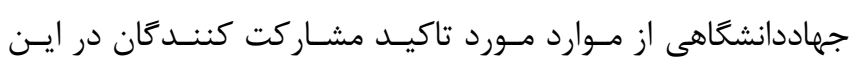

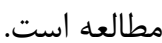

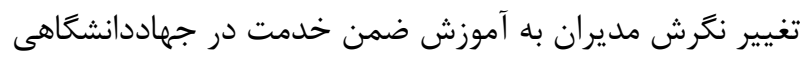

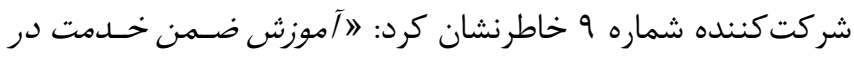

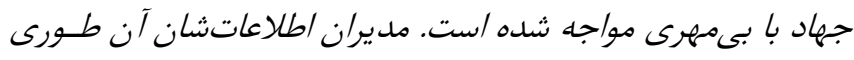

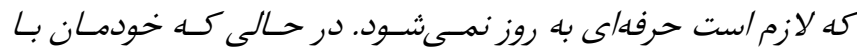

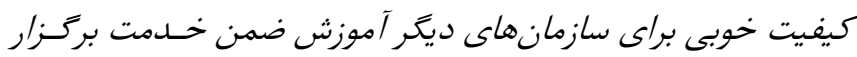

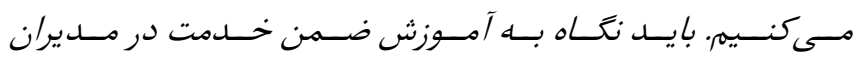
جهادد/نشكاهى تغيير كند. به نظرم سطح مناسب تحصيلات مديران

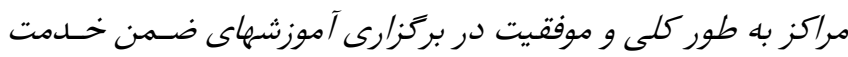

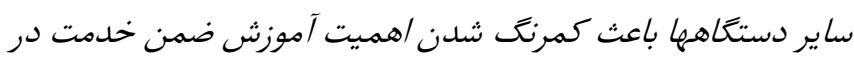

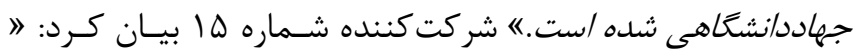

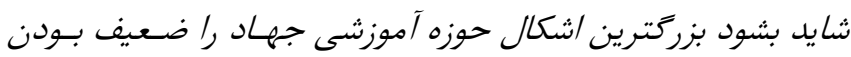

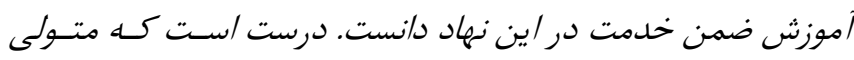


مجازى مورد تاكيد مشاركت كنند كان در اين مطالعه است.

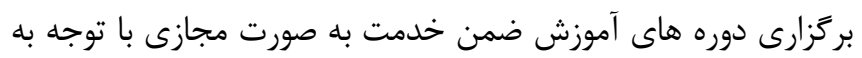
مشغله مديران شركت كننده شماره 1 كفت: البركزارى آموزش هاى ضمن خدمت بران مديران كار دشوارى است جون مشغله كارى زيادى دارند. آموزش

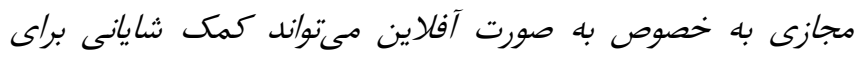
بركزارى آموزشهاى ضمن خدمت مديران باشد. بايد طورى دورهماى لهاى

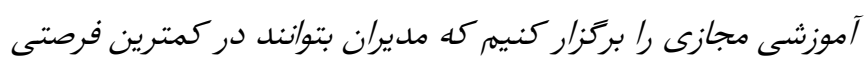

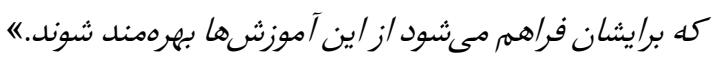

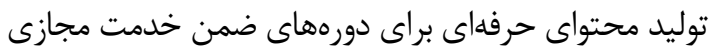

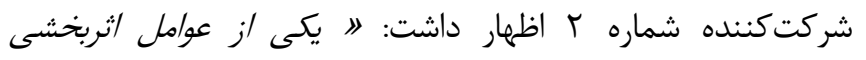

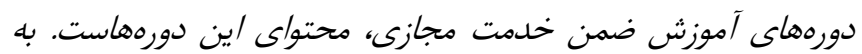

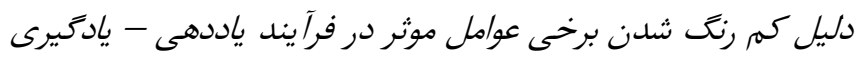

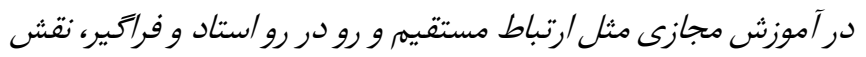

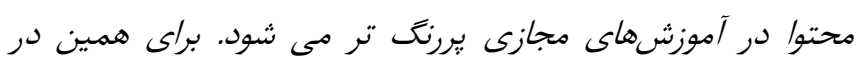

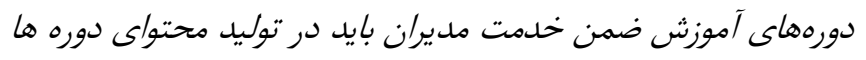

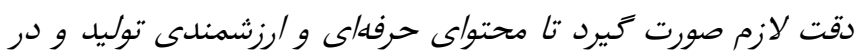

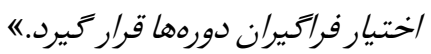

خدمت انجام شود، در طول زمان صـرفه جـويى قابل ملاحظـه اى در

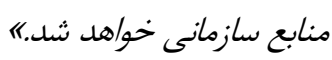

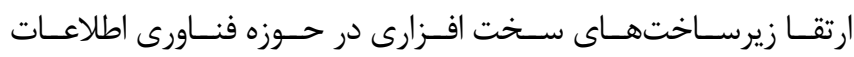

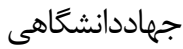
شركت كننده شماره ها با بيان اين كه يكى از اصلىترين قدمها براى

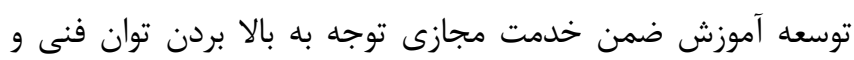

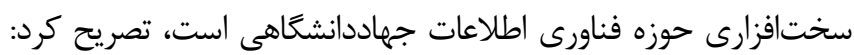

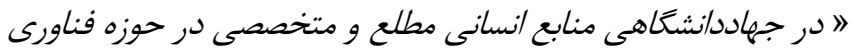

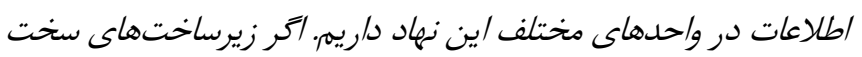

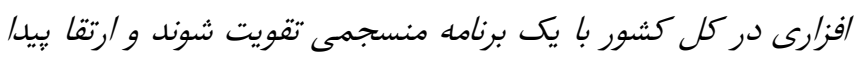
كنند، با وجود /ين منابع انسانى قوى قطعا تحول /ساسى در آموزش هائى مجازى جهادد/نشكاهى اتفاق خواهد يافت. /ين مساله همر برائ

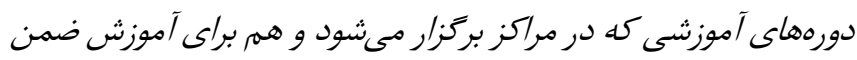

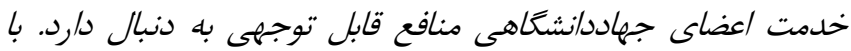
توجه به هزينهاى هنكفت زيرساخت فناورى اطلاعات، دفتر مركزى

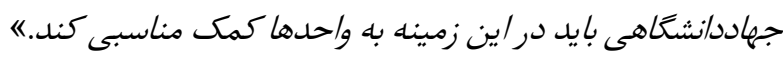

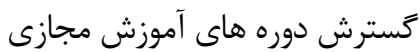
بركزارى دورههاى آموزش ضمن خدمت به صورت مورت مجازى بـ با توجه به

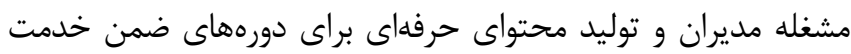

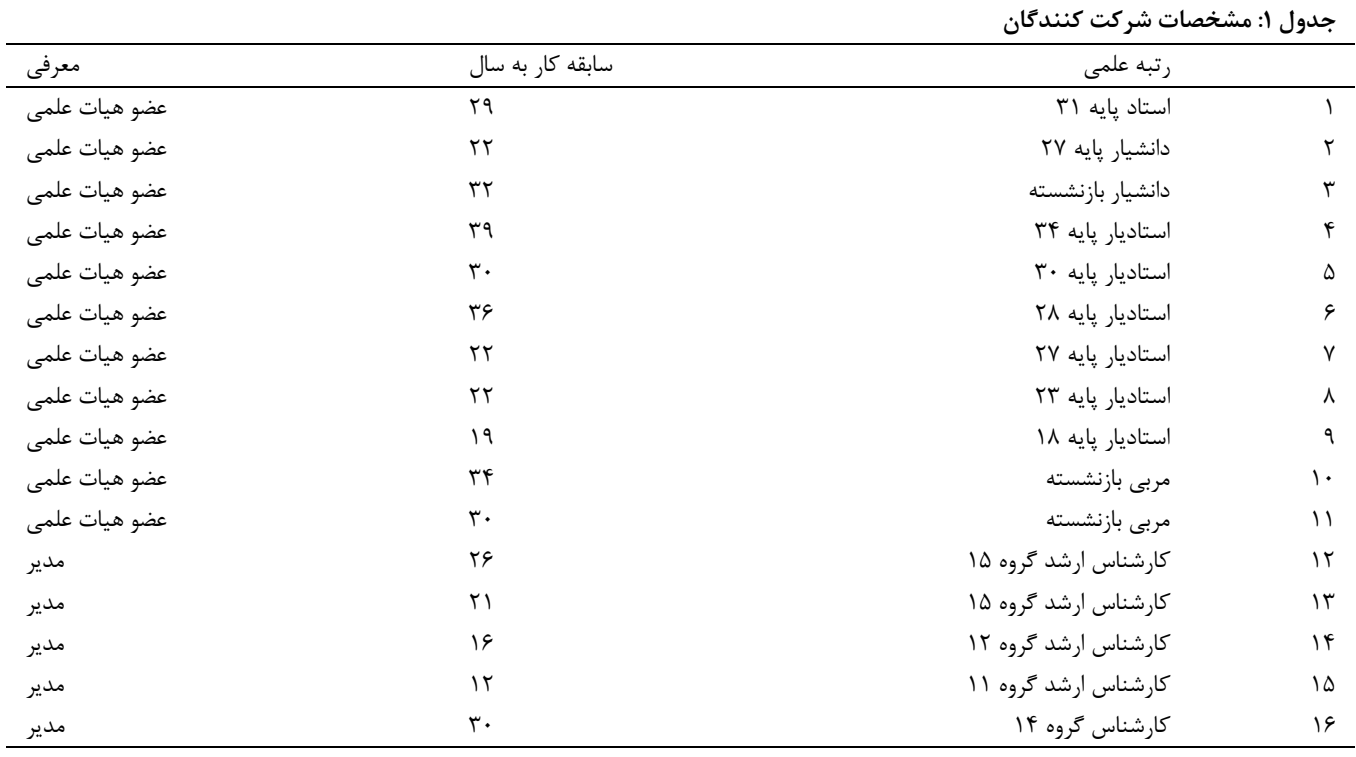


سال بيسته، شماره اول، بهمن ـاسفند 99\%1\%

جدول r: عوامل موثر بر بهبود آموزشهاى ضمن خدمت مديران مراكز آموزش

\begin{tabular}{|c|c|c|}
\hline مفهوم (كد اوليه) & مضمون هاى فرعى & مضمون اصلى \\
\hline ا - شركت در آموزشهاى ضمن خدمت درون جهاددانشًاهى & 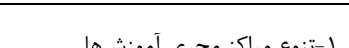 & \\
\hline r r شركت در آموزشهاى ضمن خدمت خارج از جهاددانشكاهى & ا-ننوع مرار مجرى اموزسها & \\
\hline 1-1آموزش ضمن خدمت در حوزه مديريت مالى & & \\
\hline ك r-آموزش ضمن خدمت در حوزه مذاكره & & \\
\hline بــآموزش ضمن خدمت در حوزه مديريت آموزشى & & \\
\hline ب أموزش ضمن خدمت در حوزه خلاقيت & 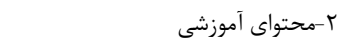 & \\
\hline هـ-آموزش ضمن خدمت در حوزه تبليغات & & \\
\hline 9- بآموزش ضمن خدمت در حوزه مديريت منابع انسانى & & عوامل آموزشى \\
\hline V V آموزش ضمن خدمت در حوزه فن بيان & & \\
\hline 1- ابهرهبردارى از تجارب موفق درون جهاددانشًاهى & & \\
\hline ك-بهرهبردارى از تجارب موفق مراكز آموزشى داخلى & & \\
\hline ك- بهرهبردارى از تجارب موفق مراكز آموزشى خارجى & 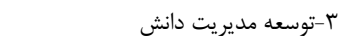 & \\
\hline 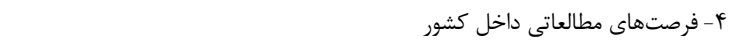 & & \\
\hline هـفرتهاى مطالعاتى خارج كشور & & \\
\hline 1-لزوم بازنترى در آييننامه آموزش ضمن خدمت اعضاى جهاددانشًاهى & & \\
\hline r- ارتقا جايگًاه آموزش ضمن خدمت در مقررات انتصاب مديران مراكز & ا-بازبرى در وواين & \\
\hline بـارتقا جايكاه آموزش ضمن خدمت در مقررات ارتقا مديران مراكز & & \\
\hline 1-تغيير نكَرش مديران به آموزش ضمن خدمت در جهادانشكاهى & ז- سياستهاي آموزشي & 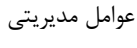 \\
\hline r r ارتقا جايكاه آموزش ضمن خدمت در برنامههاى توسعه جهاددانشكاهى & & \\
\hline 1- ارتقا نرم افزاهاى آهوزش ضمن خدمت الكترونيكى در جهاددانشكاهى & 1-ت ا-توسعه زيرساخت آموزشهاى مجازى & \\
\hline r - ارتقا زيرساختهاى سخت افزارى در حوزه فناورى اطلاعات جهاددانشكاهى & & \\
\hline ا - بركزارى دوره هاى آموزش ضمن خدمت به صورت مجازى با توجه به مشغله مديران & r - توسعه آموزشهاى مجازى & \\
\hline ك- توجه به محتواى حرفهاى در دوره هاى ضمن خدمت مجازى & & عوامل فناورانه \\
\hline
\end{tabular}




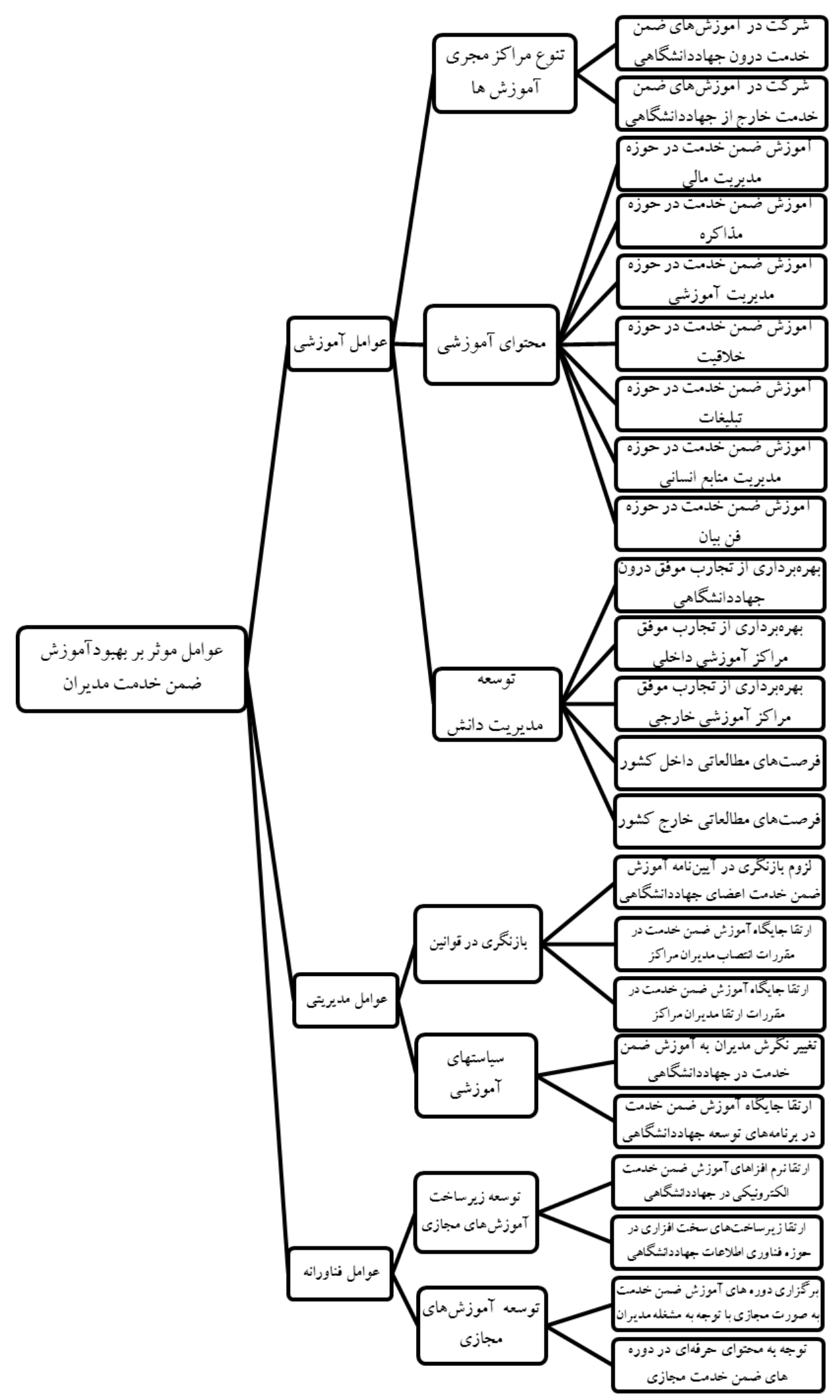

شكل ا: عوامل موثر بر بهبود آموزش ضمن خدمت مديران 
درست نيازهاى آموزشى و يرهيز از بركزارى دورههاى آموزش ضمن خدمت فاقد اولويت يكى از اصول اساسى بركزارى اين دوره هاسئ.

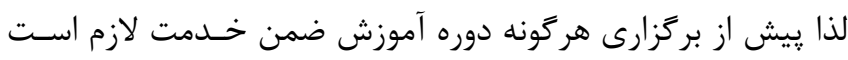

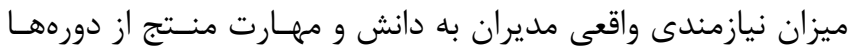

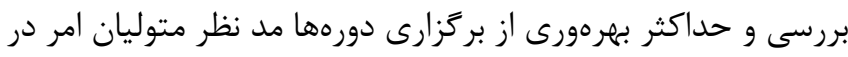

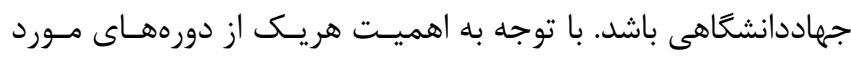

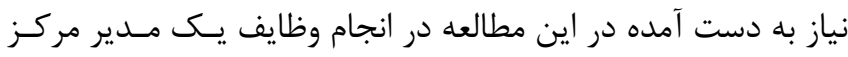

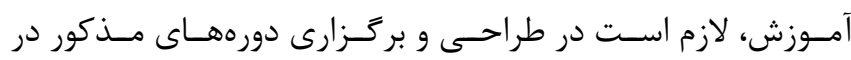

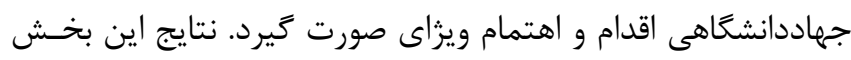

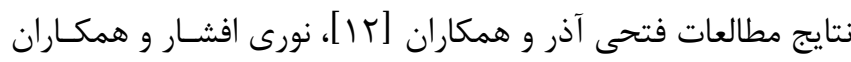

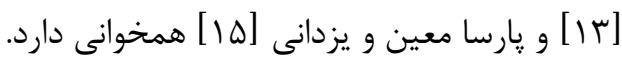

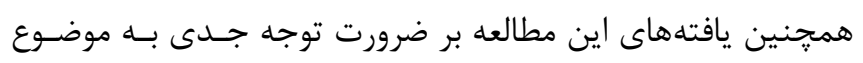

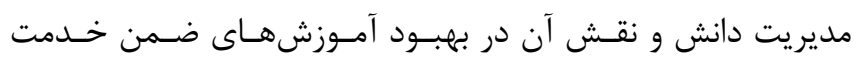

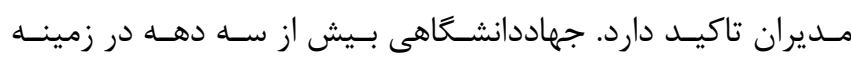

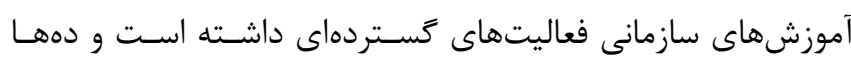

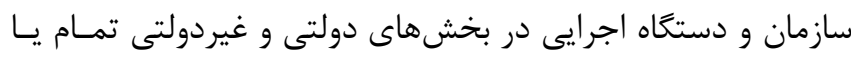

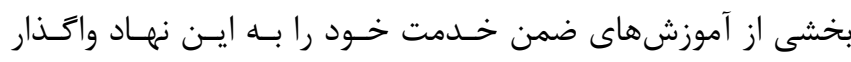

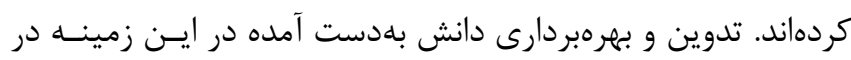

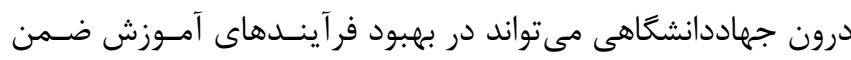

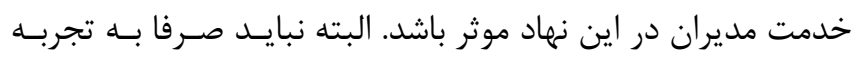

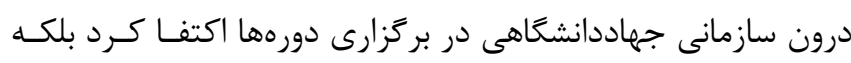

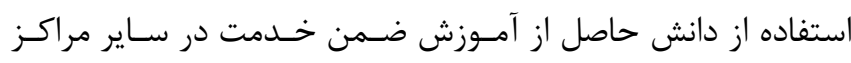

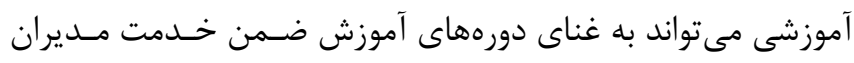

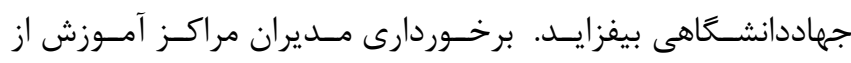

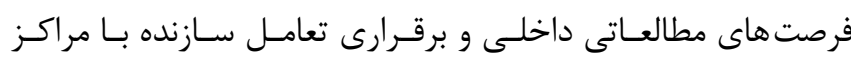

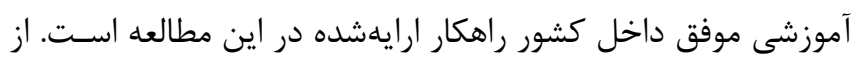

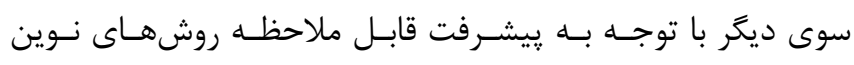

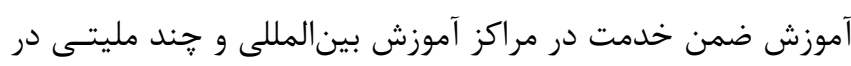

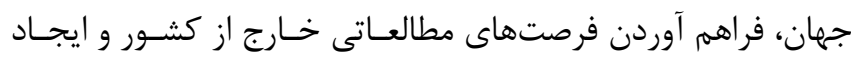

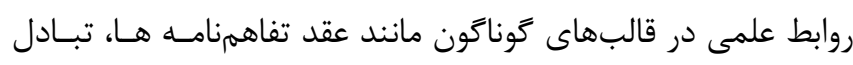

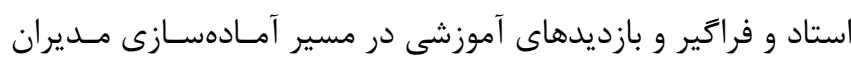

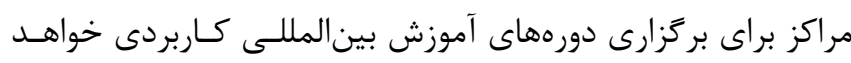

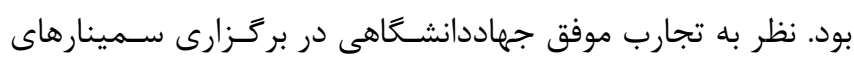

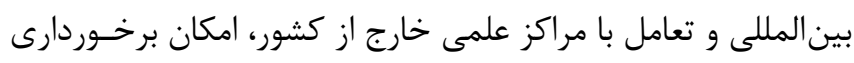

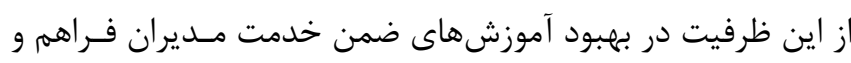

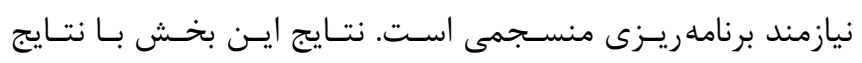

\section{بحث و نتيجه گيرى}

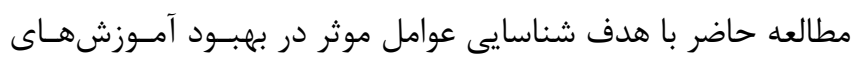

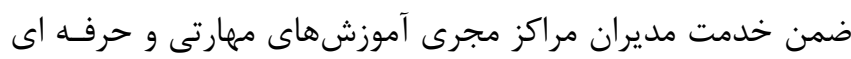

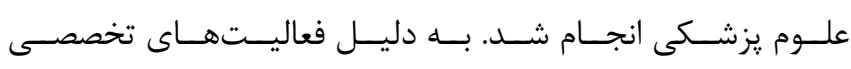

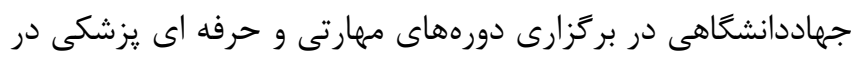

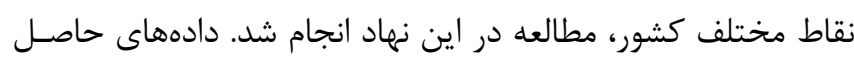

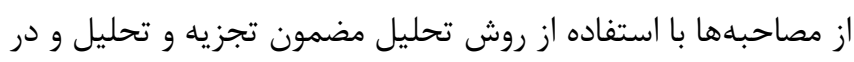

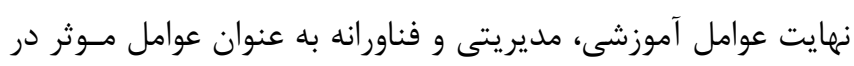

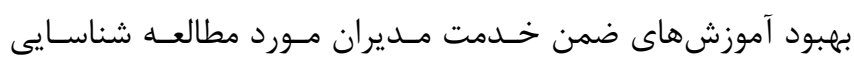

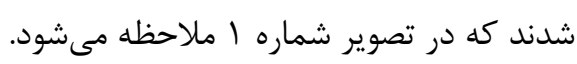

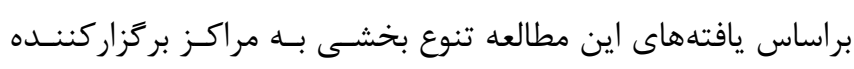

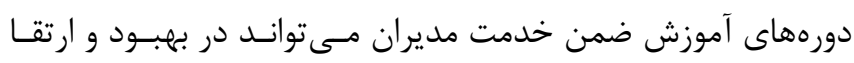

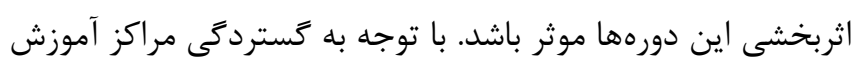

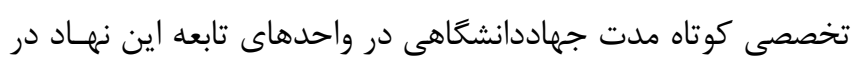

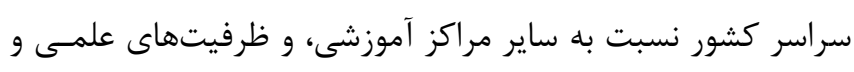

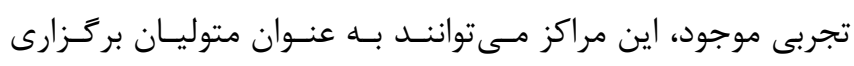

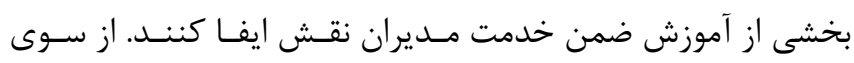

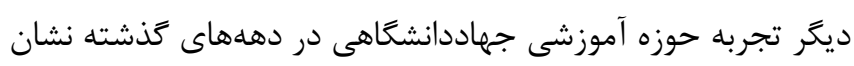

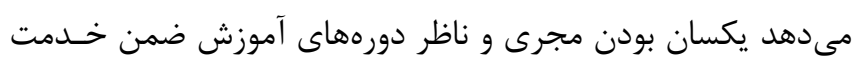

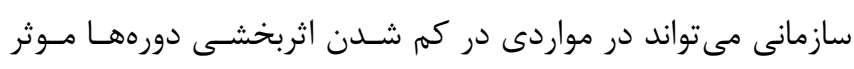

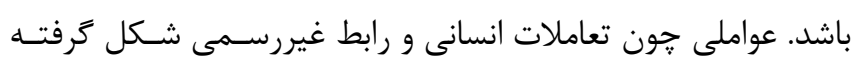

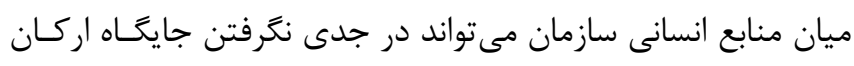

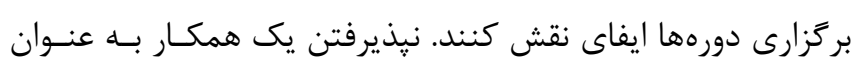

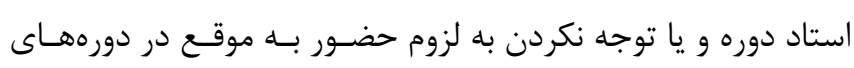

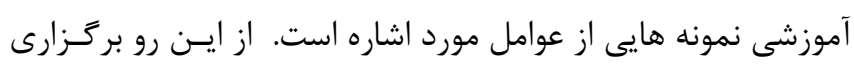

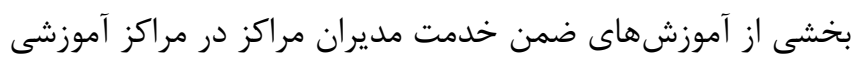

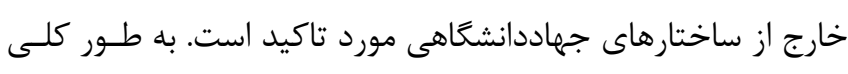

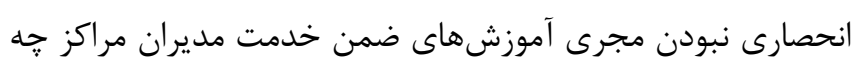

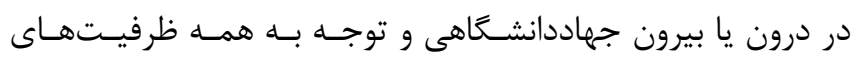

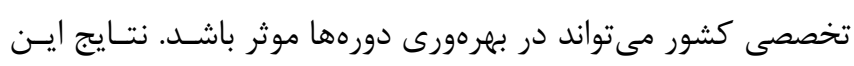

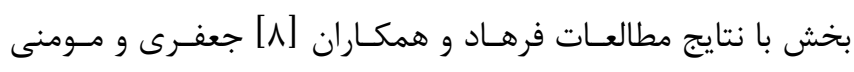

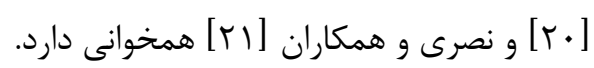

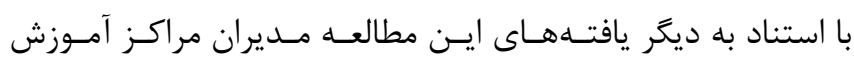

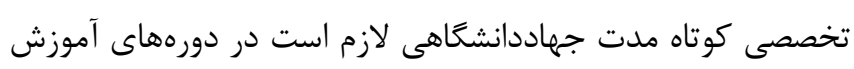

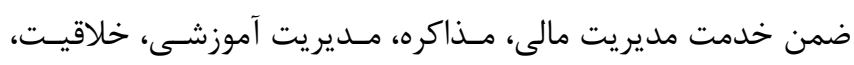

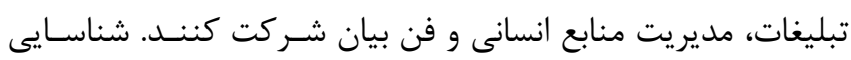


يشتيبانى و مديريت منابع در دفتر مركزى اين نهاد و در واحـدهاى

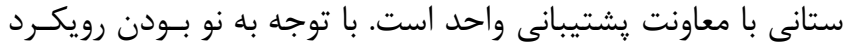
جديد جهاددانشكاهى به آموزش ضـمن خــدمت در ايسـن نهـاد لازم است توجه جدى ترى جهـت اجـــاى سياسـتهــاى اعـلام شــده در

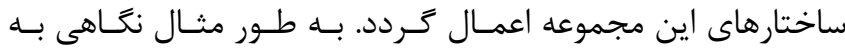

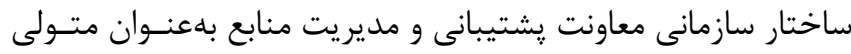

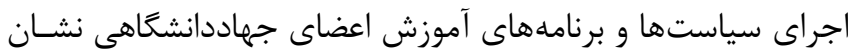

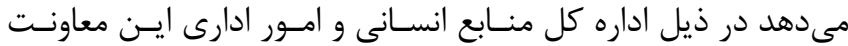

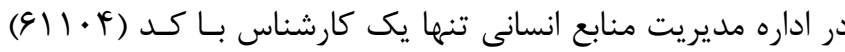

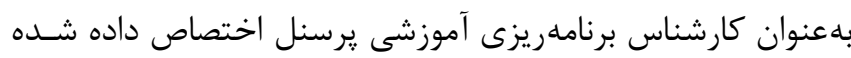

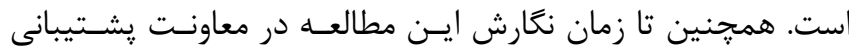

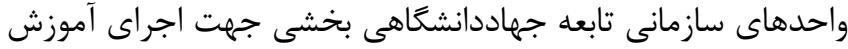

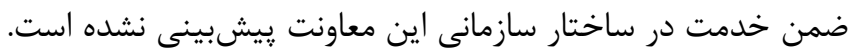

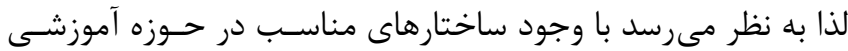
جهاددانشكاهى ايجاد ساختارى با هماهنگى معاونتهاى يشتيبانى و

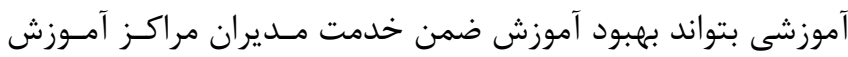

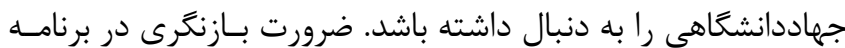

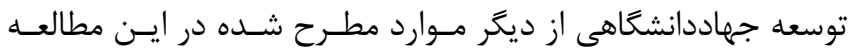

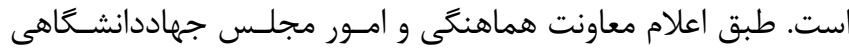
به عنوان متولى تدوين برنامههاى توسعه جهاددانشخاهى اين برنامـهـ

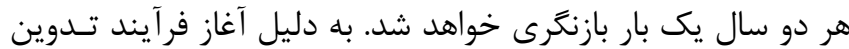

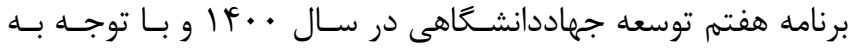

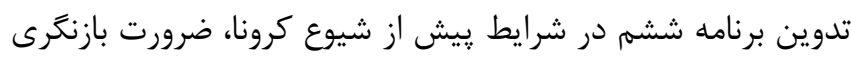

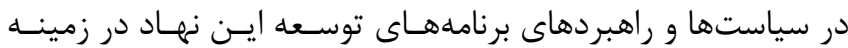
آموزش ضمن خدمت اعضا احساس مىشود. ايـن برنامـهـ بـه عنـــان

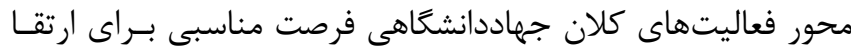
جايكاه آموزشهاى ضمن خدمت اعضا به ويزه مديران در ايـن نهـاد فئاد

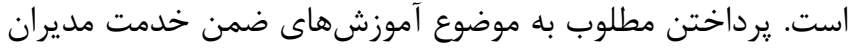

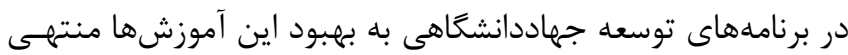

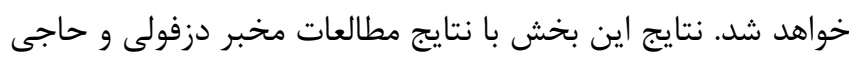

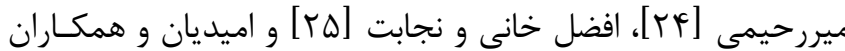

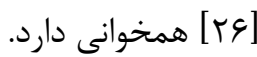
يافتهاى اين مطالعه نشان مىدهد عوامـل فناورانـهـ شـامل توسـعه

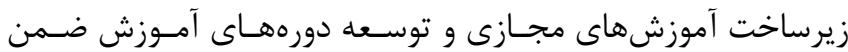

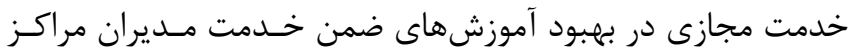

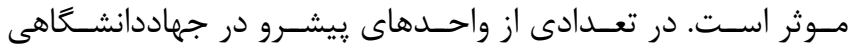

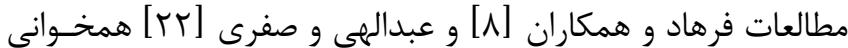

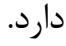
براساس ديخر يافتههاى اين مطالعه بازنخرى در قوانين مـورد تاكيـد

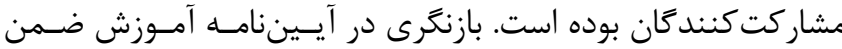

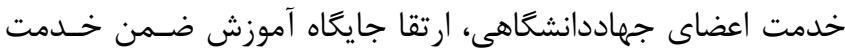

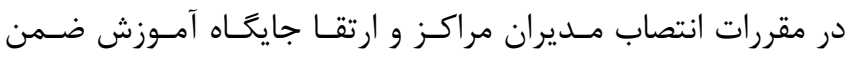

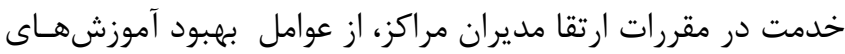

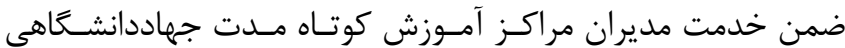

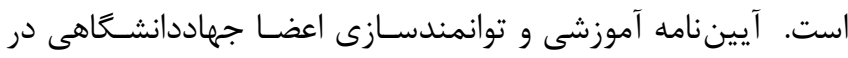

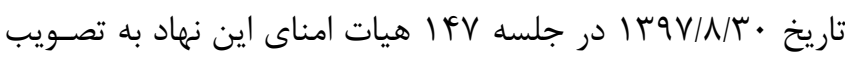

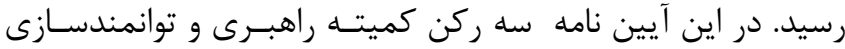

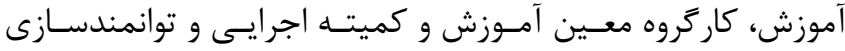

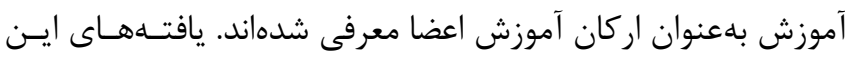

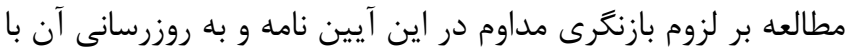

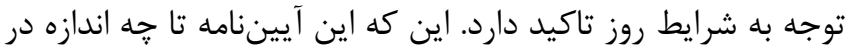

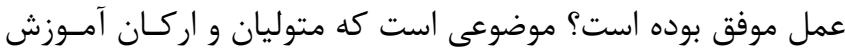
ضمن خدمت اعضاى جهاددانشكاهى بايد بررسى كرده و نـواقص آن آن

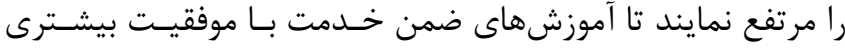

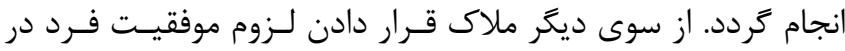

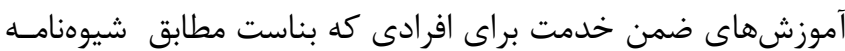

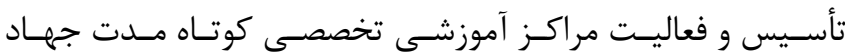
دانشخاهى و آييننامه تاسيس و بهرهبردارى مراكز آموزش مهـارتى حرفهاى علوم يزشكى به مديريت مركز منصوب شوند، توجه جدى إنتر به موضوع آموزش ضمن خدمت مديران و به تبع آن موفقيت بيشتر

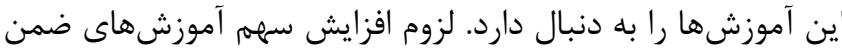
خدمت در ارتقا سازمانى مديران يكى ديكر از يافتههاى اين مطالعـهـ است. تعيين آموزشهاى ضمن خدمت سالانه و تعيين وزن مناسبى

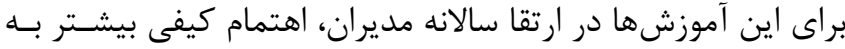

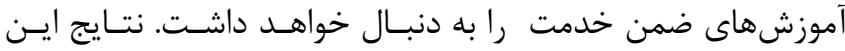

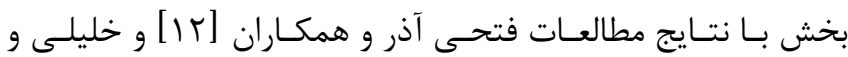
همكاران [r/ [ب] همخوانى دارد. از ديكر يافتههاى اين مطالعه مىتوان به نقش تغيير نكَرش مـديران

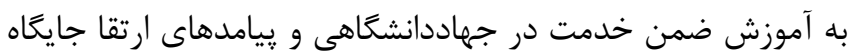
آموزش ضمن خدمت در سياستهاى برنامههاى توسعه اين نهاد در

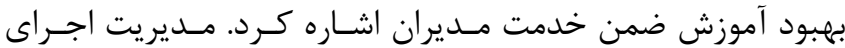

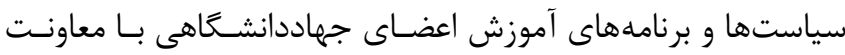


آموزشهاى علوم يزشكى رقم زد. با توجه به همكـارىهـاى گَسـترده

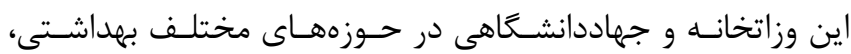

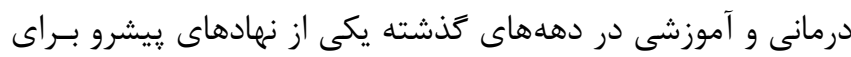
توسعه آموزش مهارتى و حرفهاى علوم يزشكى با همكارى اين مركز

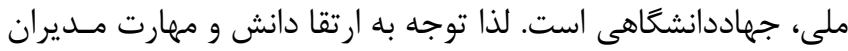

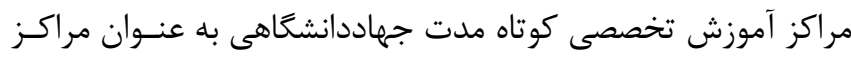

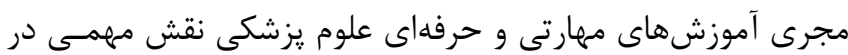
اين همكارى ايفا مى كند. يافتههاى اين مطالعه بر تقويـت و توستعه

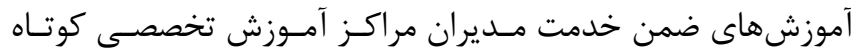

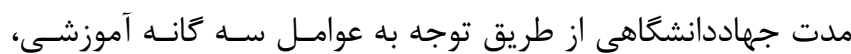
مديريتى و فناورانه تاكيد دارد. با توجه به رويكرد كيفى اين مطالعـهـ

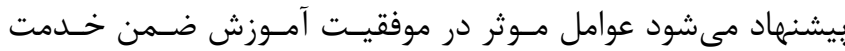

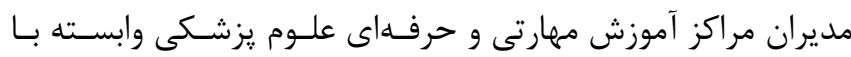
دانشعاههاى علوم يزشكى و بخشى خصوصى در مطالعات جداكانهاى إنى

$$
\text { نيز مورد شناسايى قرار كيرد. }
$$

\section{سمم نويسند}

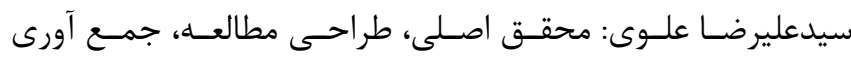
اطلاعات، تجزيه و تحليل داده ها، نكارش مقاله محمد حسين يور: طراحى مطالعه و ويرايش نهايى مقاله يداله مهرعلى زاده: مشاوره علمى و وير ايش نهايى مقاله

\section{تشكر و قدردانى - - ت}

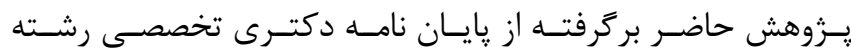

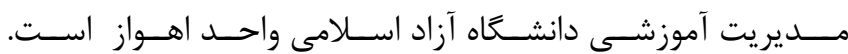

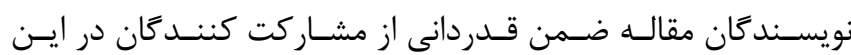

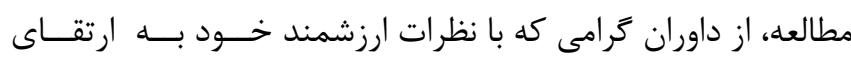
كيفيت اين مقاله كمك كردند، سياسگزارند.

\section{منابع}

1. Shukla A, Singh Sh, Rai H, Bhattacharya A. Employee Empowerment Leading to Flexible Role Orientation: A Disposition Based Contingency Framework. IIMB Management Review 2018; 21: 12-25 2. Young J, Yusliza M, Ramayah T, Jabbour C, Sehnem S, Mani v. Pathways Towards Sustainability in Manufacturing Organizations: Empirical Evidence on the
ظرفيتهاى مناسبى در زيرساختهاى مـورد نيـاز بـراى ايجـاد يـــ دئس

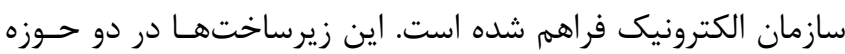

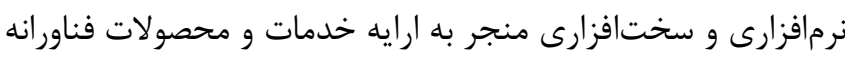

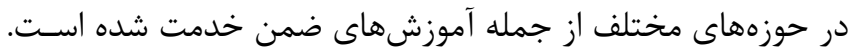

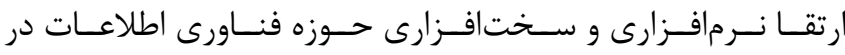

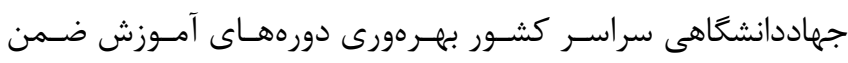

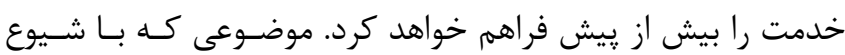

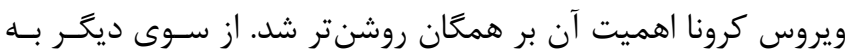

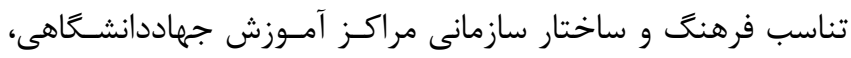

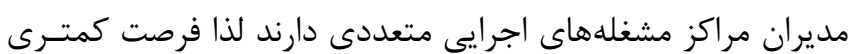

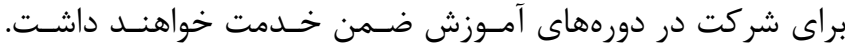
افزايش سهم آموزشهاى ضمن خدمت مجازى در سبد آموزشهاى

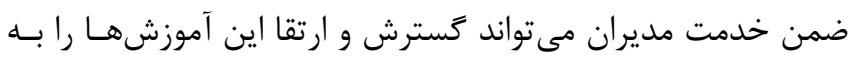

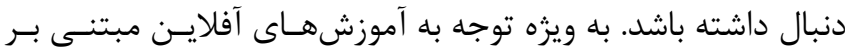

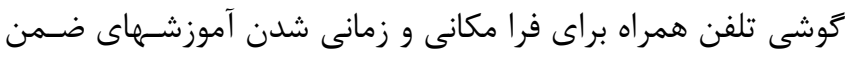

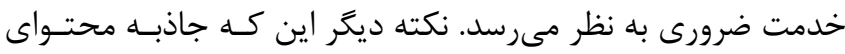

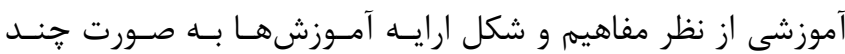

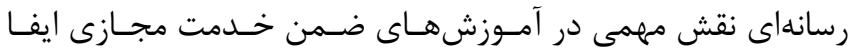

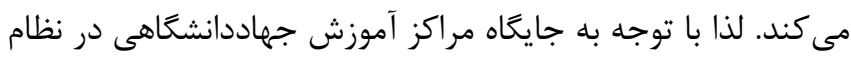

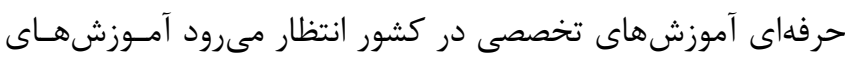

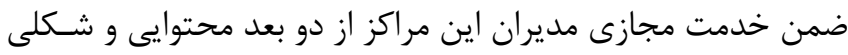

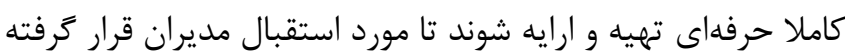

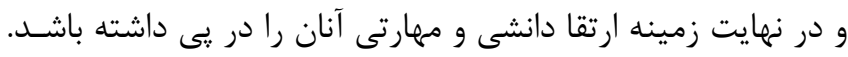

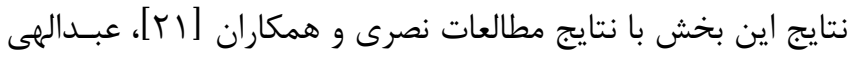

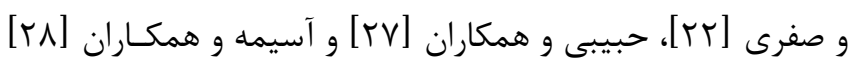

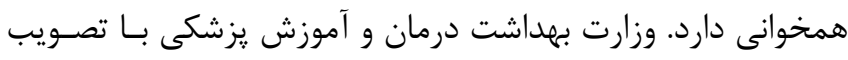

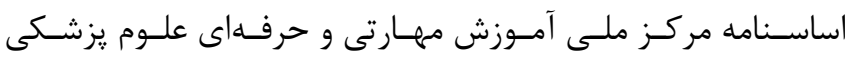

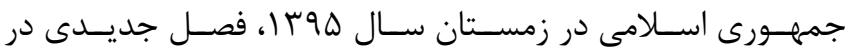

Role of Green Human Resource Management. Business Strategy and the Environment 2020; 29: 221-228

3. Sehhat S, Sajadian, F. Emploees' Perception of Commitment Based Human Resource Practice. Management Studies in Development and Evolution 2019; 91: 31-63 [Persian]

4. Mokhniuk A, Yushchyshyna L. The Impact of Monetary and Non-Monetary Factors of Motivation on 
Employee Productivity. Journal of Lesia Ukrainka Eastern European National University 2018; 13: 94101

5. Imani M, Rezaeisirous $S$, Sharifi A. Developing a Return on Investment (ROI) Model in Training and Improving Human Resources (Case study: Tehran Municipality). Quarterly Journal of Career \& Organizational Counseling 2020; 42: 179-198 [Persian]

6. Damirchi M, Hosseini S, Oladian M. Designing an Empowerment pattern for Sepah bank staff based on Organizational Learning. Quarterly Journal of Training \& Development of Human Resources 2019; 20: 1-25 [Persian]

7. Eslami N, Hoseini M, Makarem A, Gholami H. A Survey on the Effect of In-Service Training Courses on The Satisfaction, Educational, and Assessment Skills of the Academic Staff of Mashhad University of Medical Sciences. Journal of Mashhad Dental School 2020; 44: 3-13 [Persian]

8. Farhad S, Pardakhtchi M, Sabaghiyan Z. Pattern Design, Codification and Performance of Training Transfer in Nurses in Service Training. Journal of Nursing Education 2019; $8: 21-32$ [Persian]

9. Mahdavi Z, Fayyaz I. Identifying the Effective Factors in Effectiveness of the On-the-Job Training Courses for Presenting the Structural Model. Educational Psychology 2014; 32: 115-137 [Persian]

10. Aahancheeyaan M, Zohoorparvand v. Strategies For Improving The Effectiveness Of Organizational Training Courses. New Thoughts on Education 2010; 6: 95-126 [Persian]

11. Ghahremani Golozan A, Mostafavi A. The Impact of In-Service Training on Empowerment of Qazvin Province Government Personnel from the Point of View of its Learners. Journal of Development \& Evolution Management 2016; 23: 63-74 [Persian]

12. FathiAzar E, Adib, Y, Golparvar F. Phenomenology of Effective Factors and Motivator in Quality of In-Service Training Courses of Teachers. Research in School and Virtual Learning, 2016; 12: 47-56 [Persian]

13. Nooriafshar M, Haghverdi M, Komijani A. InService Education for Teachers: From Effectiveness to Efficiency. Journal of New Approaches in Educational Administration 2020; 41: 305-324 [Persian]

14. Abili $\mathrm{K}$, Gholamali lavasani $\mathrm{M}$, Gholami $\mathrm{K}$, Hosseini S J. The Study of Effectiveness Training Courses Supervisions' and Suggestions Suitable
Solutions in Order to its Improvement (Case Study: National Iranian Gas Company). Human Resource Management in Oil Industry 2016; 27:51-74 [Persian] 15. Parsa Moein K, Yazdani M. The Relationship between In-Service Training with Efficiency and Effectiveness of Najah Staff in Tehran. Quarterly journal of training in police sciences 2019; 25: 112130 [Persian]

16. Mohammadi $Z$, Rezghi shir savar $H$, Ziaee $M$, Hashem nia S. Identifying On-the-Job Training indices and determining their relationship with staff's Performance Improvement (case: Iran Forensic Medicine Organization). Journal of New Approaches in Educational Administration 201937: 311-334 [Persian]

17. Meke E. Teacher Motivation and Implementation of Continuing Professional Development Programmes in Malawi, The Anthropologist 2013; 107-115

18. Yap Q, Webber J. Developing Corporate Culture in a Training Department: A Qualitative Case Study of Internal and Outsourced Staff .Review of Business \& Finance Studies 2015; 1:43-56

19. Macleani I. In-Service Training and Teachers' Job Performance in Public Senior Secondary Schools in Rivers Stat International Journal of Scientific Research in Education 2018; 11: 493-520

20. Jafari M., Momeni G. Effective Factors in the Job Training Quality among the Northern Khorasan Police Command Staff. Applied Research Bureau of the police force of Northern Khorasan 2016; 9: 95-114. [Persian]

21. Nasri S, Karampoor A, Pirooznia M. Examining ways to qualify the In-service Trainings. Technology of Education Journal 2016; 3: 247-261 [Persian]

22. Abdollahi B, Safari A. The Study of Key Barriers to the Teachers' Professional Development. Educational Innovations, 2016; 2: 99134 [Persian]

23. Khalili H, Saadatmand Z, Derakhshan $M$. Investigate Promotion Ways Of Educational Courses For Naja Students In 1393-94. Research in Curriculum Planning 2017; 51:159-175 [Persian]

24. Mokhber A, Alipoor H. Improvement Factors of Staff Training Courses and Motivational Methods for Employees Participation Development in These Courses "Case Study: Ministry of Agriculture Jihad". Journal of Agricultural Education Administration Research 2017; 41: 110-129 [Persian] 25. Afzalkhani M, Nejabat S. Strategies to Increase Inservice Terms of Teachers and Personnel in Semnan 
Education Organization. Journal of New Approaches in Educational Administration 2013; 15: 83-98 [Persian]

26. Omidian F, Dehghani M, Roumezi H. Evaluate the Implementation and Impact of Adult Education, inService Courses on Teachers and Integrated and Independent School Administrators Performance in Iran. Educational Development of Judishapur 2017; 8(Supplement): 20-33 [Persian]
27. Habibi H, Hamrahzade M, jafarian V.Pathology of Organizational Training Management: A Phenomenological Study. Journal of New Approaches in Educational Administration 2020; 44: 55-76 [Persian]

28. Asemeh M, Selselehgar A, Sharifzadeh M. The Role of In-service Virtual Training Courses in Job Empowerment of Employees of Fars province AgriJihad Organization. Agricultural Extension and Education Research, 2019; 3: 25-34 [Persian] 